\title{
Application of magnetic nanoparticles in nucleic acid detection
}

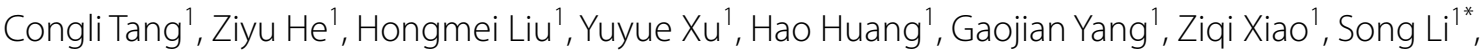 \\ Hongna Liu', Yan Deng ${ }^{1,2}$, Zhu Chen ${ }^{1}$, Hui Chen ${ }^{1}$ and Nongyue $\mathrm{He}^{2}$
}

\begin{abstract}
Nucleic acid is the main material for storing, copying, and transmitting genetic information. Gene sequencing is of great significance in DNA damage research, gene therapy, mutation analysis, bacterial infection, drug development, and clinical diagnosis. Gene detection has a wide range of applications, such as environmental, biomedical, pharmaceutical, agriculture and forensic medicine to name a few. Compared with Sanger sequencing, high-throughput sequencing technology has the advantages of larger output, high resolution, and low cost which greatly promotes the application of sequencing technology in life science research. Magnetic nanoparticles, as an important part of nanomaterials, have been widely used in various applications because of their good dispersion, high surface area, low cost, easy separation in buffer systems and signal detection. Based on the above, the application of magnetic nanoparticles in nucleic acid detection was reviewed.
\end{abstract}

Keywords: Magnetic nanoparticles, Nucleic acid detection, High-throughput sequencing, Clinical diagnosis, Magnetic separation

\section{Background}

Magnetic nanoparticles (MNPs) have the characteristics of both magnetic particles and nanoparticles (NPs), which refer to particles ranging between 1 and $100 \mathrm{~nm}$ that produce a response when presented in magnetic field. As the size of MNPs decrease, the ratio of surface area to volume increases allowing an increase with surface effect, small size effect, quantum size effect and macroscopic quantum tunneling effect. MNPs also exhibit coercivity changes and a Curie temperature decrease $[1$, 2].

MNPs are classified into metal NPs, metal oxide NPs and alloy NPs. Metal NPs includes iron, cobalt, and nickel [3]. Metal oxide NPs consist of iron oxides $\left(\gamma-\mathrm{Fe}_{2} \mathrm{O}_{3}\right.$ and $\left.\mathrm{Fe}_{3} \mathrm{O}_{4}\right)$ and ferrites $\left(\mathrm{CoFe}_{2} \mathrm{O}_{4}\right.$ and $\left.\mathrm{Mn}_{0.6} \mathrm{Zn}_{0.4} \mathrm{Fe}_{2} \mathrm{O}_{4}\right)$ [4]. Alloy NPs include FeCo and FePt [5].

*Correspondence: sosong1980@gmail.com

${ }^{1}$ Hunan Key Laboratory of Biomedical Nanomaterials and Devices, Hunan University of Technology, Zhuzhou 412007, China

Full list of author information is available at the end of the article
Some magnetic nanoparticles have superparamagnetism, which refers to the state of MNPs when introduced to an external magnetic field, in which NPs react similarly to paramagnets with the difference being the higher level of attraction, hence "super". All the MNPs are easily guided in the presence of external magnetic fields [6]. This is often used in materials science, electrochemistry, biochemical sensing, magnetic resonance imaging (MRI), environmental and medical research [7]. MNPs also play a significant role in removing pollutants and relieving toxicity, such as membrane separation for water treatment and purification. Researchers use MNPs to immobilize biomolecules (antibodies, proteins, enzymes, etc.) and utilize simple, rapid, cheap and efficient separation of target biomolecules [8-15]. Biomarkers in complex clinical samples can be preconcentrated and enriched, separating interfering matrices, and increasing the sensitivity and specificity of testing. Magnetic drug targeting utilizes drug targeted delivery in vivo through active targeted therapy strategy. In vitro detection and application of MNPs plays an important role in early rapid diagnosis 
and treatment of diseases, thus assisting in prevention, management, treatment and prognosis of diseases [16-23]. MNPs are also used for lateral flow test strips and microfluidic platforms such as lab-on-a-chip (LOC) devices for continuous flow of magnetic cell separation, and can be developed into portable devices that are easy to use. MNPs have attracted great interest of researchers due to their excellent properties [24-31].

Nucleic acid is one of the most basic substances in life and has extremely important biological functions. It mainly stores and transmits genetic information [32-36] which in turn, helps detect genetic changes that may be associated with certain health conditions [37-41]. The following is a brief review outlining the significance of nucleic acid detection in identifying important gene mutations for disease risk prediction, clinical treatment and prognosis evaluation [42-48]. Research shows that breast cancer susceptibility gene mutations are the main cause of breast cancer family clustering [49-54]. Berenstein [55] studies show that FLT3 gene mutation is one of the most frequent gene mutations in patients with Acute myeloid leukemia (AML), which can be seen in various subtypes of AMI. Kayser [56] found that C-KIT mutations are present in leukemia patients. Through gene sequencing, it can be seen that lung cancer-related genes such as epidermal growth factor receptor gene mutation, c-MET, ROS1, KRAS, and BRAF, play an extremely important role in diagnosis and treatment of lung cancer [57-71]. In addition to the above diseases, many diseases are related to gene mutations, such as Type 1 diabetes mellitus [72-75] and Type 2 diabetes mellitus [76-81], Lymphoma [82, 83], bowel cancer [84-88], and prostatic cancer [89-91]. Early nucleic acid detection is significant for identifying these gene mutations to prevent, treat, and identify disease prognosis [92].

To date, the gold standard for nucleic acid detection is polymerase chain reaction (PCR), however, this method is both time-consuming and laborious. PCR detection equipment is both large and expensive, and the operators need professional training. Therefore, it is especially important to develop fast and economical nucleic acid detection technology and equipment. The conventional nucleic acid extraction and isolation is a time-consuming process that goes through several centrifugation steps often resulting in low yield and purity. The above limitations restrict the application of such technologies for real time testing, limiting PCR to more developed central cities, hospitals and medical institutions in developed countries. PCR consumables and machines are often too expensive for low-level medical service platforms, especially in the vast rural areas and medical institutions in developing countries. In addition, the traditional PCRbased detection methods have been difficult to meet the increasing high-throughput demand in recent years for emergency treatment of sudden infectious diseases, clinical in vitro diagnosis, mobile medicine and other applications due to time restraints.

MNPs have high surface area to volume ratio, high binding rate with detection substances, and can perform magnetically controllable aggregation and dispersion, making preconcentration, purification and separation of nucleic acids simple and easy. MNPs have good dispersibility, which can bind biomolecules quickly and effectively. The binding is reversible, and the aggregation and dispersion of MNPs can be controlled. In the absence of an external magnetic field, the particles are nonmagnetic and are uniformly suspended in solution, while when an external magnetic field is used, the particles have magnetism and can be separated. Active substances such as bioactive adsorbents or other ligands connected to the surface of MNPs can be combined with specific biomolecules, like enzymes, DNA, proteins, and separated under the action of an external magnetic field. This method has high specificity, rapid separation and good reproducibility. MNPs have been applied in biosensors to improve the sensitivity of nucleic acid detection, and have been widely used in nucleic acid detection due to their excellent properties. A series of automatic detection instruments have been designed to utilize rapid and automatic detection of nucleic acid, which is of great significance in the medical field [93-99].

This article introduces the application of MNPs in nucleic acid extraction, target enrichment, infectious disease identification, site mutation detection, and library preparation for Next Generation Sequencing.

\section{Nucleic acid extraction}

Nucleic acid extraction is one of the most fundamental steps in molecular biology applications and is a prerequisite for many experiments. The quality of extracted nucleic acid will directly affect the results of subsequent detection in experiments. Traditional nucleic acid extraction methods are both time-consuming and laborious, in addition to operators requiring professional training [100]. Magnetic beads (MBs) are considered a powerful tool for nucleic acid extraction. Coupling of magnetic properties with specific ligands in MBs allows the separation and purification of nucleic acids in a highly efficient and specific manner. In fact, this technique has driven a technological revolution in biological research [101]. Pang [102] proposed a functionalized $\mathrm{Fe}_{3} \mathrm{O}_{4} @ \mathrm{Ag}$ magnetic nanoparticle biosensor to capture and ultra-sensitively detect microRNA from total RNA of cancer cells. Chen [103] developed a paper-based analytical device (PAD) for DNA colorimetric detection, which detected the specific 
recognition of nucleic acids through MNP separation and hybridization chain reaction (HCR) induced by target DNA.

Wang [104] used MNPs to simultaneously extract DNA and RNA from cancer cells. This MNP-based method has attracted great attention because of its convenient operation, low cost and easy automation. In order to extract nucleic acids efficiently and programmatically, in Li's [105] research, a rapid and high-quality universal nucleic acid extraction kit based on MBs was developed and named MB-100.

$\mathrm{Wu}$ [106] demonstrates the ease of MB automation by designing a new type of automatic sample processing device based on magnetic separation to isolate and extract both DNA and RNA. This device enables sample preparation to be completed in the field without transferring the plate to any additional equipment. Similarly, Chen [107] developed an automatic rapid nucleic acid extractor, which can process 16 samples simultaneously using MNPs. The nucleic acid extraction system can complete the whole nucleic acid extraction process within $30 \mathrm{~min}$, and the system is stable and reliable. Recently, Tavallaie [108] proposed that the recombination of gold-plated MNP networks modified by probe DNA (DNA-Au @ MnPs) induced by electric field can construct a highly sensitive sensor for analyzing nucleic acids in complex samples such as whole blood.

The method of extracting nucleic acids by MBs is widely used in various fields. Applying a magnetic field attracts the target-bound molecule towards the magnet, separating them from the unwanted material or inhibitors without disturbing the nucleic acid of your interest. The method of extracting nucleic acids by magnetic beads has become the mainstream of modern molecular biology. Table 1 details extraction applications mentioned in this paper. A major advantage of MBs application in extraction is that the aggregations do not need centrifugation, which can significantly ease

\section{Table 1 A summary of extraction}

\begin{tabular}{|c|c|c|c|}
\hline $\begin{array}{l}\text { Magnetic } \\
\text { particles }\end{array}$ & $\begin{array}{l}\text { Experimental } \\
\text { sample }\end{array}$ & Extraction target & References \\
\hline $\mathrm{Fe}_{3} \mathrm{O}_{4} @ \mathrm{Ag}$ & $\begin{array}{l}\text { HeLa, A549, } \\
\text { MCF-7 }\end{array}$ & microRNA & [102] \\
\hline $\mathrm{Fe}_{3} \mathrm{O}_{4} @ \mathrm{SiO}_{2}$ & Hep G2 & DNA/RNA & [104] \\
\hline $\mathrm{MBs@SiO}_{2}$ & $\begin{array}{l}\text { E. coli, breast } \\
\text { cancer }\end{array}$ & DNA & [105] \\
\hline MNPs & E. coli & DNA & [106] \\
\hline MBs & $\begin{array}{l}\text { Liver cancer cells, } \\
\text { E. coli }\end{array}$ & DNA & [107] \\
\hline Au@MNPs & A549 & microRNA & [108] \\
\hline
\end{tabular}

the test process and equipment requirements, thus improving efficiency and lowering cost.

\section{Enrich target substance}

Using MNPs for target enrichment capture technologies allow scientists to rapidly interrogate important genomic regions of interest for variant discovery including infectious disease detection, Single Nucleotide Polymorphism (SNP), gene isoforms, and structural variation which highly improves the accuracy and sensitivity assays and greatly reduces the experimental cost and turnaround time.

Pathogens pose an increasing threat to public health worldwide. It is particularly important to establish a rapid enrichment and sensitive detection method to identify these pathogens. Here we review multiple researchers that have utilized MNPs to detect pathogens. Zhu [109] constructed $\mathrm{Fe}_{3} \mathrm{O}_{4} /$ Vancomycin/PEG magnetic nanocarrier, which can efficiently enrich Listeria monocytogenes and prepare its nucleic acid in situ for subsequent gene detection (Fig. 1). Chen [110] proposed a magnetic separation (MS) and magnetic relaxation switching (MSMRS) sensor in which MB250 and MB30 selectively capture and enrich targets to form a "MB250-target-MB30" structure to detect Salmonella enteritidis and viruses in milk. This method integrates target enrichment, extraction and detection into one step by using MNPs (Fig. 2). Kwon [111] developed a colorimetric method by combining platinum-coated MNP clusters (Pt/MNCs) with magnetophoretic chromatography to enrich the target with $\mathrm{Pt} / \mathrm{MNC}-\mathrm{EC}$ complex to achieve the naked eye detection of Escherichia coli in milk. Wang [112] first synthesized gold magnetic nanoparticles (AuMNPs) core-shell nanocomposite, then synthesized plasma vibrator AunRDTNB NPs, combined with staphylococcus aureus antibody to form a SERS label sandwich structure for enrichment and detection of Staphylococcus aureus. Cheng [113] combines aptamer and antibiotic-based dual recognition units with magnetic enrichment and fluorescence detection (Fig. 3), and specifically captures staphylococcus aureus with aptamer-coated magnetic beads (Apt-MB). Liu [114] used streptavidin modified MNPs (SA-MNPs) for rapid enrichment and sensitive detection of Escherichia coli O157:H7, Salmonella enteritidis, Vibrio cholerae and Campylobacter jejuni in food. Wang [115] proved that $\mathrm{Fe}_{3} \mathrm{O}_{4}$-Ce6-Apt nano-system can identify and enrich blood bacteria, and can detect the enriched bacteria by fluorescence microscopy. Kaur [116] developed a rapid and sensitive method of "Miod", which includes target bacterial cell enrichment based on MNPs, followed by cell lysis and nucleic acid loop-mediated isothermal amplification (LAMP) with signals measured by 


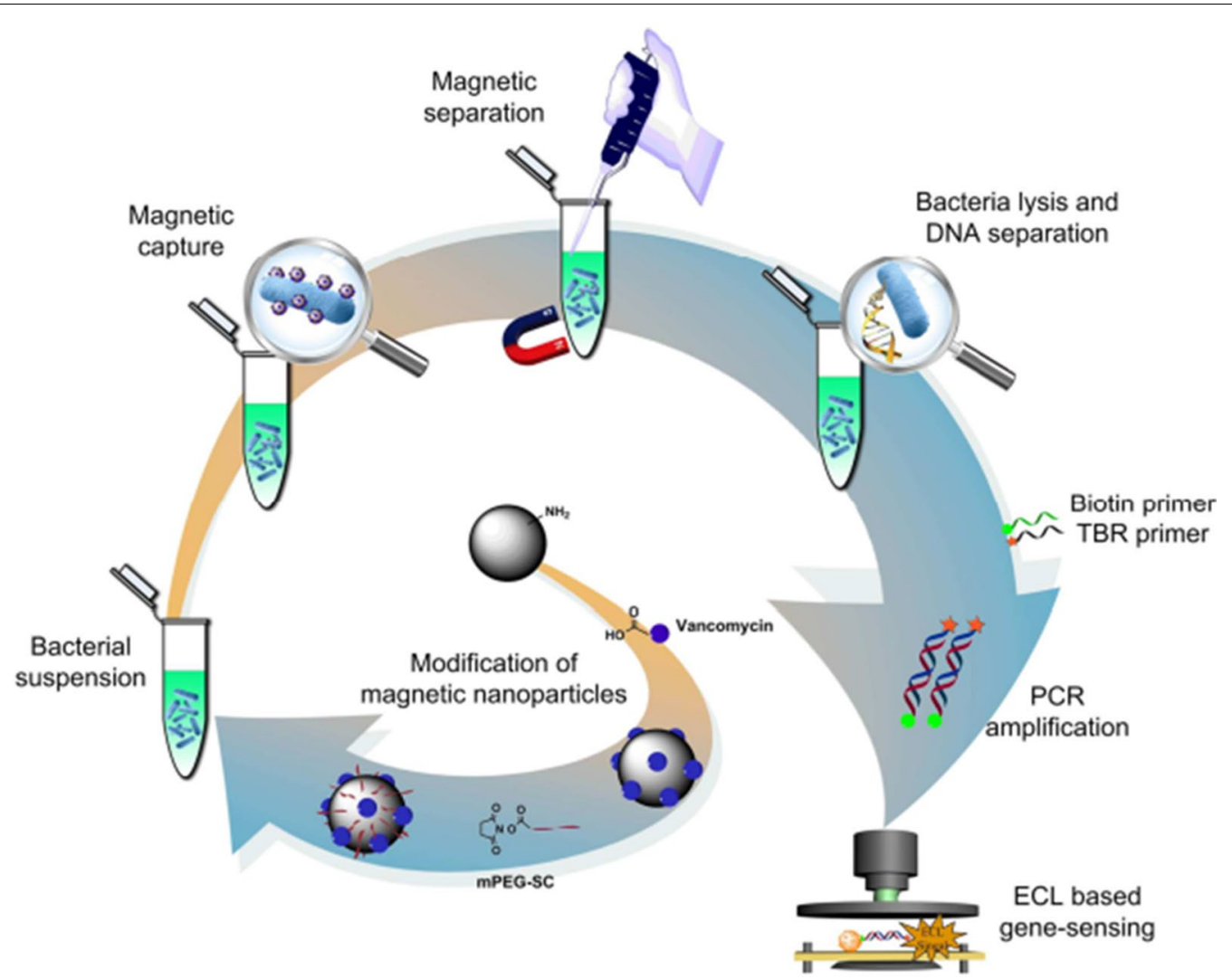

Fig. 1 The schematic procedure of the integrated bacterial enrichment/gene-sensing system with $\mathrm{Fe}_{3} \mathrm{O}_{4} /$ vancomycin/PEG nanocarrier [109]

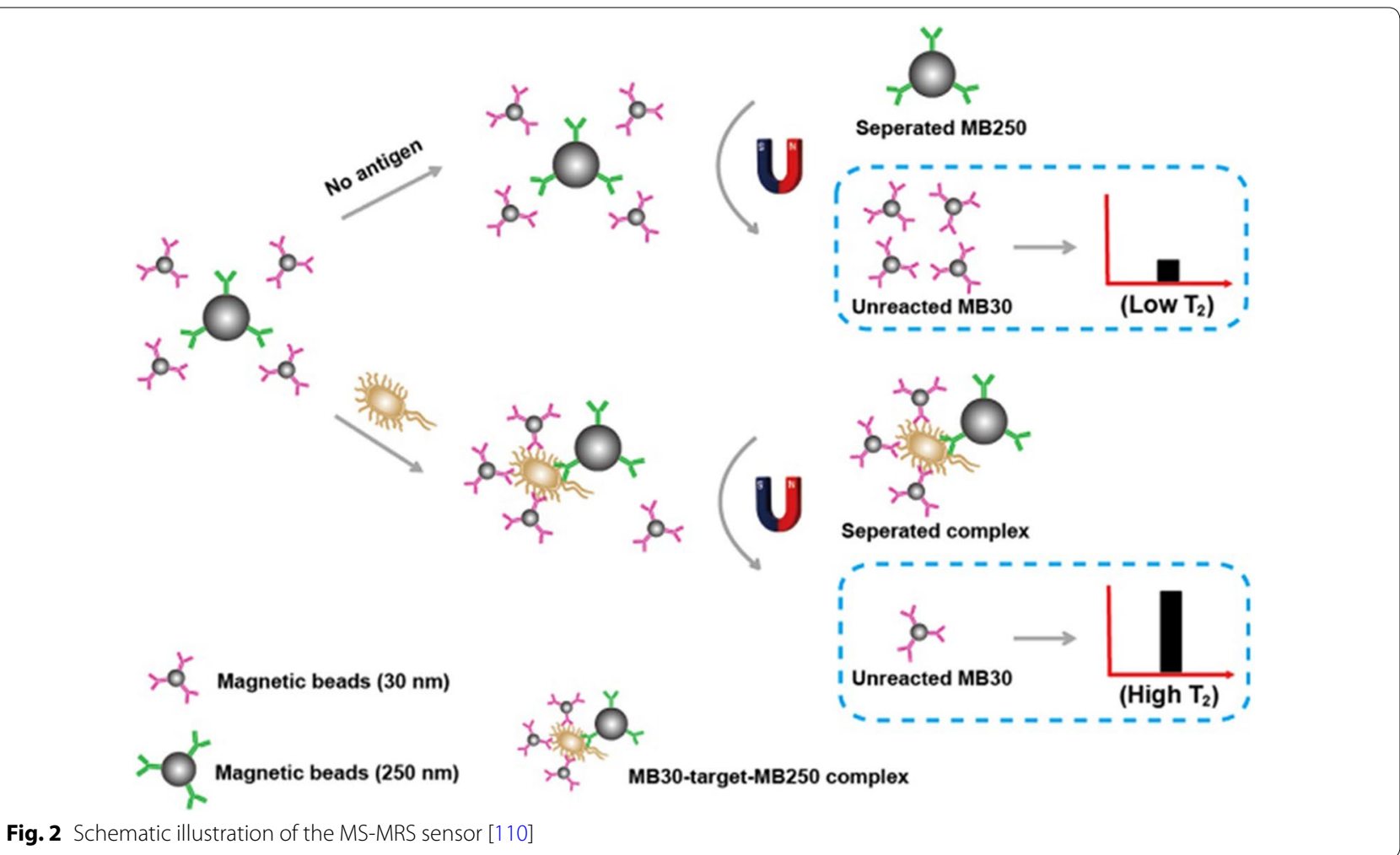



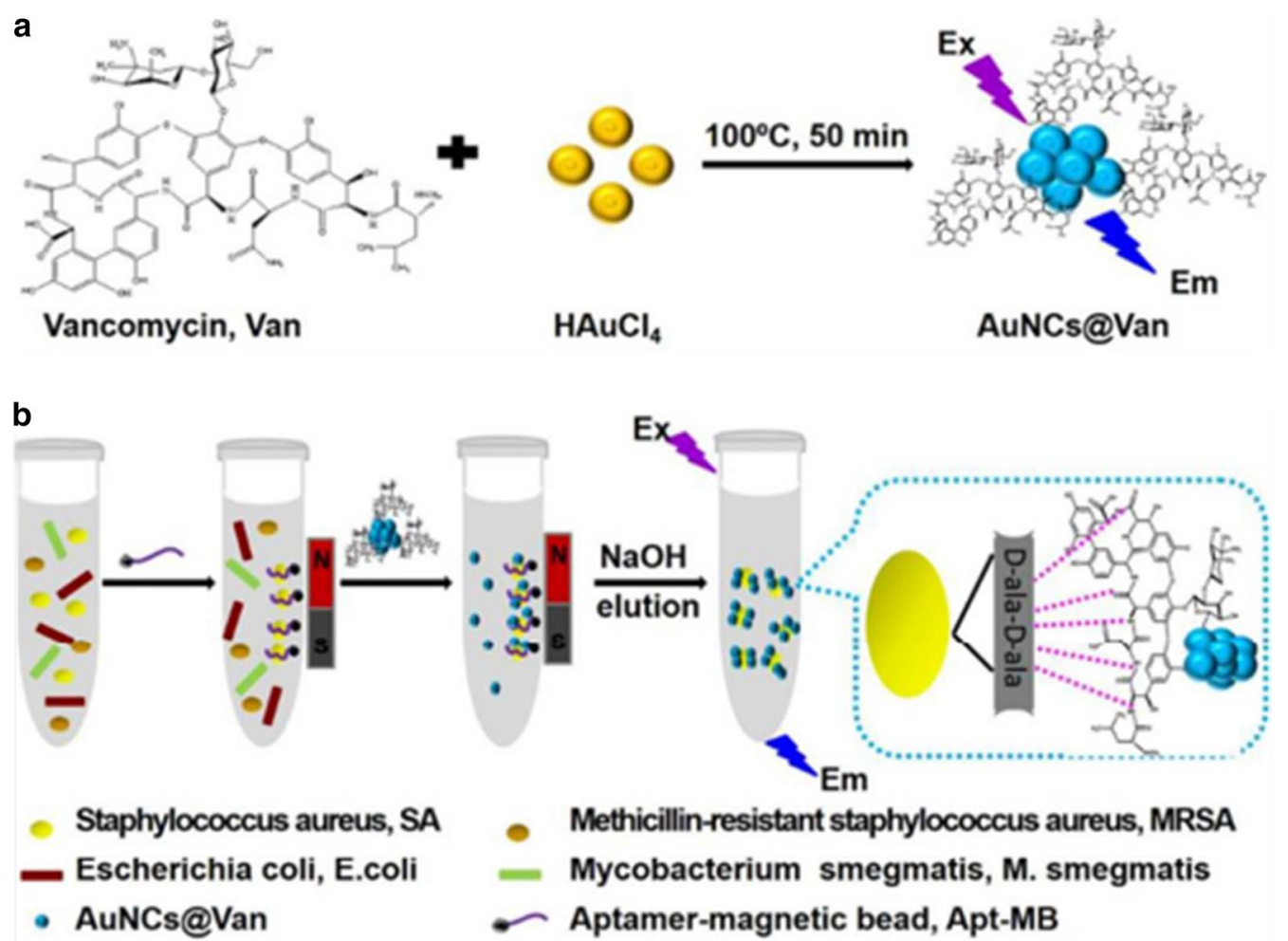

Fig. 3 Schematic illustrations of a one-step preparation of AuNCs@Van, and $\mathbf{b}$ determination of SA in mixtures using the Apt-MB and AuNCs@Van dual recognition strategy [113]

an in situ optical detection system to identify positive/ negative enteric fever infections.

In addition to detecting gene mutations, the detection of tumor markers plays an important role in the early screening of many cancers. In Wang's [117] report, using double template MNPs as capture probes with alpha-fetoprotein (AFP) and carcinoembryonic antigen (CEA) as template proteins, which were synthesized by self-polymerization of dopamine (DA) on $\mathrm{Fe}_{3} \mathrm{O}_{4} \mathrm{NPs}$, enriched the targets simultaneously and identified AFP and CEA. Zhao [118] uses magnetic liquid to manipulate particles and cells in a microfluidic system, guiding the movement of particles and cells in a label-free and low-cost manner, and by this method, particles and cells can be enriched. Hong [119] reported multi-functional magnetic nanowires with high density of MNPs and five different types of antibodies (Ab mixture-mPpyNWs), which can enrich cells and monitor captured circulating tumor cells (CTC) in real time by simple colorimetric immunoassay. In previous studies, Xiong's research group [120] synthesized $\mathrm{Fe}_{3} \mathrm{O}_{4}$ magnetic nanoclusters (MNCs) with high magnetization, uniform size and positive charge. On this basis, biomimetic immune magnetosomes (IMSs) are continually being developed for highly efficient enrichment of CTCs. In Liu's study [121], magnetic iron oxide NPs were coupled with over-expressed folate receptor (FR) and stably attached to the surface of ovarian cancer (OC) cells, thus making the cells magnetic and enabling nondestructive OC cell enrichment and whole blood detection.

Enrichment of target substances, removal of impurities and purification of detection objects provides great sensitivity and convenience for downstream experiments. Table 2 shows enrichment in target substances using applications mentioned in this paper.

\section{Nucleic acid detection}

The high binding capacity, specificity of binding, and the fast-magnetic response makes MNPs ideal for nucleic acid detection in high-throughput samples requiring fast turn-around time.

\section{Infectious disease identification}

MBs introduce a new technical approach of nucleic acid isolation by coupling with molecules that bind specifically to nucleic acids and can be easily isolated by applying magnetic fields (Table 3).

Parham et al. [122] developed a specific and efficient DNA capture method that is compatible with both PCR and non-amplification detection technologies for Group B streptococci (GBS) identification. 
Table 2 A summary of enrichment

\begin{tabular}{|c|c|c|c|}
\hline Magnetic particles & Experimental sample & Detection limit & References \\
\hline $\mathrm{Fe}_{3} \mathrm{O}_{4}$ /Vancomycin/PEG & L. monocytogenes & $10 \mathrm{cfu} / \mathrm{mL}$ & [109] \\
\hline MBs & S. enterica & $100 \mathrm{cfu} / \mathrm{mL}$ & [110] \\
\hline Pt/MNCs & E. coli O157:H7 & $10 \mathrm{cfu} / \mathrm{mL}$ & [111] \\
\hline Au@MNPs & S. aureus & 10 cells $/ \mathrm{mL}$ & [112] \\
\hline AuNCs@Van & S. aureus & $70 \mathrm{cfu} / \mathrm{mL}$ & [113] \\
\hline MNPs & E. coli O157:H7, S. enterica, C. jejuni, V. cholerae & 0.2 cells $/ \mathrm{mL}$ & [114] \\
\hline $\mathrm{Fe}_{3} \mathrm{O}_{4}$ & S. aureus, E. coli & $10 \mathrm{cfu} / \mathrm{mL}$ & [115] \\
\hline MNPs & S. typhi & $5 \mathrm{cfu} / \mathrm{mL}$ & [116] \\
\hline \multirow[t]{2}{*}{$\mathrm{Fe}_{3} \mathrm{O}_{4}$} & AFP & $0.3 \mathrm{pg} / \mathrm{mL}$ & [117] \\
\hline & CEA & $0.35 \mathrm{pg} / \mathrm{mL}$ & \\
\hline MNPs & HCT-116, MCF7 & - & [119] \\
\hline $\mathrm{Fe}_{3} \mathrm{O}_{4}$ & MCF-7, $\mathrm{HepG} 2, \mathrm{CaCO}_{2}$ & - & [120] \\
\hline IO-FA & SKOV3, A549 & $(4-10) \times 10^{6}$ cells $/ \mathrm{L},(3.5-5) \times 10^{9}$ cells $/ \mathrm{L}$ & [121] \\
\hline
\end{tabular}

Table 3 A summary of infectious detection

\begin{tabular}{|c|c|c|c|}
\hline Magnetic particles & Experimental sample & Detection limit & References \\
\hline MBs & Group B streptococci & $1.25 \times 10^{3} \mathrm{cfu} / \mathrm{mL}$ & [122] \\
\hline MBs & S. Enteritidis & $1 \mathrm{cfu} / \mathrm{mL}$ & [123] \\
\hline MBs & CPV-2 & $3 \times 10^{4}$ copies $/ \mathrm{mL}$ & [124] \\
\hline MNPs & H9N2, H1N1, H7N9 & $2 \times 10^{-2} \mathrm{pg} / \mathrm{mL}$ & {$[125]$} \\
\hline $\mathrm{SiO}_{2} @ \mathrm{MNPs}$ & HBV, HCV, HIV-1 & $10,10,100 \mathrm{cfu} / \mathrm{mL}$ & [126] \\
\hline MBs & $\begin{array}{l}\text { Chagas disease, human brucellosis, bovine brucellosis, } \\
\text { foot-and-mouth disease }\end{array}$ & - & [127] \\
\hline GMBN & S. choleraesuis & $5 \times 10^{5} \mathrm{cfu} / \mathrm{mL}$ & {$[128]$} \\
\hline MBs & C. difficile & - & [129] \\
\hline MBs & Leishmaniosis & $\begin{array}{l}3.125 \times 10^{3} \mathrm{ng} / \mathrm{\mu L} \\
1 \times 10^{3} \mathrm{cell} / \mathrm{s} / \mathrm{mL}\end{array}$ & [131] \\
\hline AuMagNBs & Influenza virus A & $4.42 \times 10^{-14} \mathrm{~g} / \mathrm{mL}$ & [132] \\
\hline
\end{tabular}

Superparamagnetic beads were functionalized with oligonucleotide capture probes of different lengths used to capture GBS genomic DNA (gDNA). Captured DNA was then detected using quantitative PCR. Sequencespecific hybridization capture on magnetic microbeads when combined with target amplification approaches such as PCR or with signal amplification technologies such as polymeric biosensors, could provide a rapid and sensitive method for nucleic acid detection from diverse organic samples. This technology could be combined with sample preparation and detection technologies in a microfluidic system to allow point-of-care testing. Zeinhom [123] developed a novel magnetic nano biosensor, which uses MBs coated with SA and biotin-labeled antibodies against Salmonella enteritidis to capture Salmonella enteritidis in milk, cheese and water, while visual quantitative detection is carried out through signal amplification by horseradish peroxidase (HRP).
Zhuang [124] used a magnetic virus DNA kit to extract DNA/RNA for PCR reaction. Once the PCR products were purified by a MB-PCR purification kit, a fluorescence lateral flow immunoassay was carried out. The study combined both PCR and fluorescence lateral flow immunoassay based on magnetic purification analysis to identify quantitative detection of hepatitis $C$ virus type 2. This scheme can be further applied to clinical analysis. Wu [125] used fluorescent MNPs for simultaneous detection of H9N2, H1N1 and H7N9 avian influenza viruses. The application of the MNPs can capture and separate target chains without sample pretreatment, and single particle counting can be performed by fluorescence. This method has simple signal amplification steps, high detection sensitivity and great potential in early diagnosis of various diseases.

Ali [126] advanced that silica modified MNPs were used to extract virus (HBV, HCV and HIV) nucleic acids and amplify them. MNPs modified by three 
different probes were incubated with RT-PCR biotin-labeled products in different tubes to capture their $\mathrm{HBV}, \mathrm{HCV}$ and HIV sequences respectively. Finally, 3-(2'-spiroadamantane)-4-methoxy-4-(3'phosphoryloxy) phenyl-1,2-dioxetane was added and chemiluminescence $(\mathrm{CL})$ was recorded. This method can achieve high throughput, automation and simultaneous detection of multiple nucleotide sequences.

María designed a biosensor based on electrochemical magnetic microbeads [127]. The platform is portable, durable and inexpensive. Experiments have verified its detection function in on-site diagnosis of human (Chagas disease and human brucellosis) and animal (bovine brucellosis and foot-and-mouth disease) infections. This platform technology can also be used to diagnose other infectious and non-infectious diseases. In Xia's research [128], gold magnetic bifunctional nanobeads (GMBN) were used to prepare immunochromatographic test strips for the detection of Salmonella choleraesuis. The immunochromatographic test strip can be applied to food samples such as whole milk. In their research, Jacquelyn [129] proposed to use the combination of $\mathrm{MB}$ aggregation and microfluidic manufacturing technology to detect pathogens. In this experiment, the LAMP product was coupled with the product inhibition bead aggregation and used to detect the target sequence of Clostridium difficile. Chen [130] designed a new point-of-care test (POCT) system based on MNPs. After testing the performance of the instrument, an automatic real-time adenovirus detection experiment was carried out. The experimental results are similar to those of commercial systems, proving the reliability of the system. Margarita [131] used MB capture probes to separate Leishmania specific surface antigen and DNA from the solution for cadmium selenite quantum dot detection. These methods have great potential in clinical application of human and veterinary medicine.

Recently, Sangjin [132] combined magnetic nanobeads (MagNBs) and gold nano-particles in silica shell to carry out enzyme-linked immunosorbent assay to monitor, reduce the spread, and provide immediate clinical treatment to influenza A virus. Feng's [133] liver samples treated with MBs were tested for Yersinia pestis by LAMP. The combination of MBs and LAMP is a simple, rapid and sensitive detection method, suitable for field or poor areas. Fang [134] designed a high flux magnetic separation module and a heating and vibration module, which can collect a large number of purified nucleic acids from pathogens of infectious diseases. In the experiment, the system is applied to nucleic acid extraction of human whole blood, and has the capability of high-throughput sample preparation to diagnose infectious diseases.

\section{Mutation site detection}

Single nucleotide polymorphism (SNP) is the most common variation in the human genome. The study of SNPs helps to explain the phenotypic differences of individuals, the susceptibility of different groups and individuals to complex diseases, their tolerance to various drugs, and their responses to environmental factors [135]. Some SNPs are mutation sites of disease-causing genes, which have practical research significance and application prospect in various aspects such as susceptibility assessment, early diagnosis, prevention and treatment of diseases $[136,137]$. Due to the special physicochemical properties and biocompatibility of MNPs such as, high separation speed, high efficiency, reusability, simple operation, no need of expensive instruments and no influence on the activity of separated substances, they have been widely used in various biological detections.

Early on, Mirkin's group [138] used short DNA modified NP labeled with hundreds of biological barcoded DNA (Bbc-Au NP) as a signal probe and another DNA modified magnetic microparticle (Oligo-MMP) as a capture probe to form a Bbc-Au NP/DNAtarget/Oligo-MMP hybrid structure after complementary pairing. The unlabeled detection and SNP detection of the target DNA can be detected at the same time. Ngo [139] used a sandwich hybridization method to detect a specific DNA sequence of plasmodium falciparum, and distinguished SNPs of wild-type malaria DNA and mutant malaria DNA. The method used loading report probe on ultra-bright SERS nanorattle, while using a magnet to concentrate the hybridization sandwich for SERS measurements. This scheme is simple and convenient and has great potential for integration into portable instruments, although is limited by the number of samples.

Based on the shortcomings mentioned above, Liu [140] designed a high-throughput SNP genotyping based on solid-phase PCR on MNPs with dual-color hybridization for detection the C677T polymorphisms of methylenetetrahydrofolate reductase (MTHFR) gene. This method solves the waste of nanoparticles. Using the PMMA/ $\mathrm{Fe}_{3} \mathrm{O}_{4}$ nanocomposite particles synthesized by Wang [141] for the SNP genotyping, the PCR reaction was directly carried out on the surface of streptavidin-coated magnetic nanoparticles SA-MNPs. The results showed that the dual-color probes have three fluorescence patterns on the microarray, differentiating three different genotypes. All reactions can be carried out in the same container without any purification, concentration and other processes [142]. This is a simple and labor-saving SNP genotyping method, and the typing result is intuitive and accurate. It can be applied to automated systems to realize high-throughput SNP detection. However, due to the need to design a pair of special two-color fluorescent 
probes for each SNP site to be analyzed, this method is relatively expensive. Tang [143] uses the same method as the above principle, with MNPs to carry out PCR and dual-color fluorescence hybridization to detect SNP sites in Pseudomonas aeruginosa exoS gene.

With deepening research, Li [144] designed a highthroughput, automated SNPs genotyping method based on AuMNP arrays and dual-color single base extension. The advantage of this assay is that it does not need to carry out necessary procedures for purification and complex reduction of PCR products, simplifying the process and increasing the potential for automation. Firstly, the biotin-labeled primer was captured by SA-GMNPs, the ssPCR product was hybridized with the primer to carry out dual-color single base extension, the fluorophoreGMNP complex of each sample was fixed on the slide, and the genotype of each sample was determined by measuring the fluorescence intensity of the fluorophoreGMNP complex on the array. Li [145] then designed a universal label for high throughput SNP genotyping to detect C667T, A1298C, M235T, G93A. The universal tag probe sequence is divided into three parts, one end of which is an allele-specific probe, and the middle of which is connected with 11 bases of polyT. The other end is connected with $\mathrm{Cy} 3$ or $\mathrm{Cy} 5$ labeled universal detector. The genotype of the sample is distinguished by the detection of fluorescent signals. The universal label probe technology is applied to detect the typing of multiple SNP sites by using a pair of fluorescent labeled probes, thus greatly reducing the typing cost.

AuNPs make ligase chain reaction a simple SNP genotyping method. Shen [146] prepared two kinds of AuNPs coated with capture probes. The correctly paired target DNA hybridized with it's complementary probe, then heated up to denature all the double-stranded structures formed, followed by exponential amplification, resulting in the formation of AuNPs aggregates whose color changed from red to purple/gray (Fig. 4). Min [147] proposed to use ExoIII nuclease and MNPs for SNP typing and detection, which use double-probe detection system with signal amplification. This method amplifies the detected fluorescence signal by 6063 times and has high selectivity and sensitivity. Yan [148] used the PCR-gold magnetic lateral flow assay system (PCR-GoldMag LFA) to make the SNP typing results visible to the naked eye without the need for other signal collectors.

In another report, Hui [149] reported for the first time that the system of combining amplification refractory

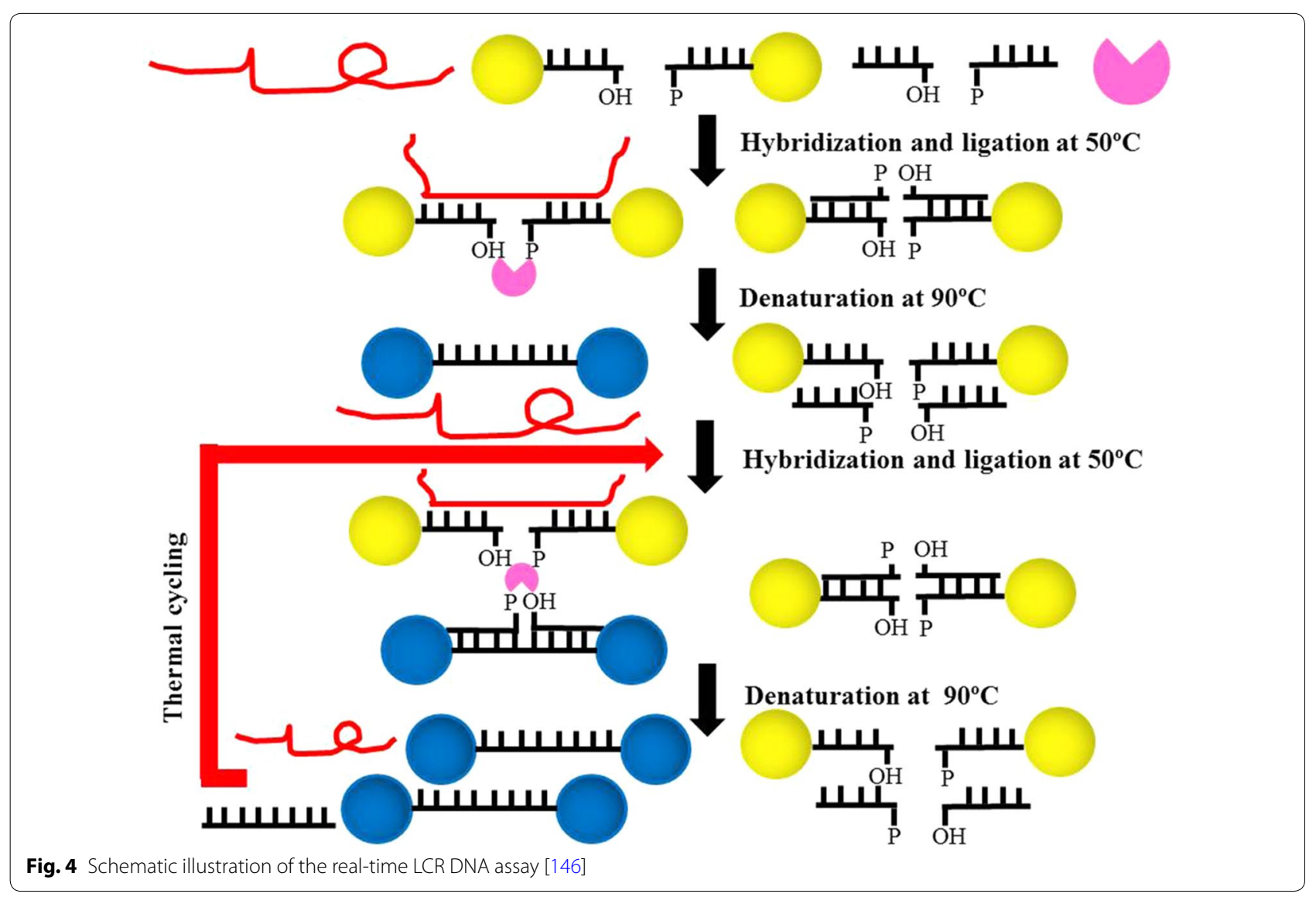


mutation system (ARMS)-PCR with GoldMag based lateral flow analysis (LFA) for genotyping was applied to the genotyping of MTHFR C677T. PCR-LFA can be extended to detect other SNPs of genes related to disease risk, drug metabolism or drug response.

Previously, in Liu's [150] research, we reported a sensitive, low-cost and easy-to-use POCT system, which was formed by combining ARMS PCR with GMNPs and LFA called ARMS-LFA system. This method simultaneously used uniform conditions to detect multiple SNPs. In this study, 7 pathogenic SNPs in phenylalanine hydroxylase gene were genotyped.

DNA methylation is the earliest found relation to gene silencing in epigenetic mechanisms [151-153]. This refers to the process of adding methyl groups to the $5 \mathrm{c}$ end of cytosine in cytosine-guanine dinucleotides $(\mathrm{CpG}$ sites) to convert cytosine into 5-methylcytosine [154, 155]. Research shows that DNA methylation modification can regulate the expression of specific genes through a variety of ways, including affecting the development process of cells and maintaining cell stability. Once methylation modification appears abnormal, it can cause the occurrence of differing diseases [156, 157].

Liu [158] used DNA modified AuNPS combined with an enzyme linked reaction to monitor DNA methylation. The double-stranded DNA molecules modified on the surface of AuNP were first methylated by DNA adenine methylation (Dam) methyltransferase and then cleaved by methylation sensitive restriction endonuclease DPN I. Removing double chains from the surface of AuNP through methylation/cleavage process will make the NPs unstable, resulting in aggregation of AuNP and color change from red to blue. Therefore, the enzyme activity of dam MTase and DNA methylation can be detected (Fig. 5).

Ge [159] used a method based on the color change of solution caused by AuNP enrichment to observe and detect DNA methylation. The probe was released by thermal denaturation and added to the unmodified AuNP solution. Salt induced aggregation was used for colorimetric detection. Compared with other methods using sodium bisulfite and methylation-specific restriction enzymes, this method provided a simpler rapid DNA methylation detection.

Through a new HCR-BRCA strategy, Bi [160] developed a CL method for methylation detection and MTase activity determination to improve sensitivity. MNPs separation, reaction and detection were used. The experiments were carried out under their respective optimal conditions. This method has advantages of specific recognition of MTase and methyl sensitive endonuclease, high RCA amplification efficiency and good MNPs control, although, the current analysis steps are complicated.

Dadmehr [161] developed a very sensitive and convenient fluorescent biosensor based on $\mathrm{Fe}_{3} \mathrm{O}_{4} / \mathrm{Au}$ core/ shell NPs for rapid detection of DNA methylation. After the target unmethylated and methylated ssDNA was added, the fluorescence intensity increased linearly with the increase of unmethylated ssDNA concentration. This detection system will be applied to the early diagnosis of methylation-dependent diseases such as cancer.

\section{NGS library preparation}

MNPs are widely used in high-throughput sequencing for library preparation, purification, concentration of PCR products and subsequent nucleic acid sequencing. The magnetic target purification method allows for target purification directly from the PCR reaction. This purification removes excess salts, enzymes, primers and nucleotides through a simple washing procedure, which eliminates the need for centrifugation steps thus simplifying the purification procedure.

Zhang [162] used MNPs to separate plasma DNA and prepare plasma DNA libraries. Short cell-free mitochondrial (cf-mt) DNA fragment was obtained by using size selection to separate out the shorter DNA fragments.

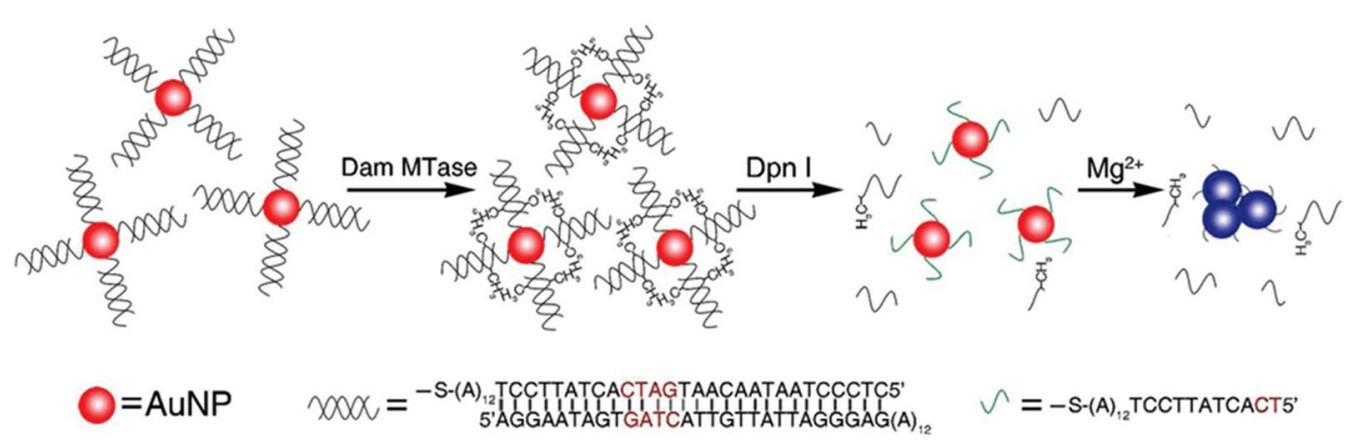

Fig. 5 Schematic illustration of the proposed strategy for methylation detection [158] 
This method was applied to plasma samples of septic patients and the heterogeneity of mtDNA in plasma of 3 patients was detected. This study is of great significance to the importance of MNPs in the discovery of the architecture of cfDNA and their biomarkers. Fadeev [163] explored sequencing the genome of Alteromonas HOT1A3. MBs enriched PCR products in this experiment and allowed this group to discover a previously undiscovered $148 \mathrm{kbp}$ plasmid.

Inflammatory bowel disease (IBD) is a chronic gastrointestinal inflammatory disease. Hall's [164] team performed a genome sequencing of fecal samples from 20 IBD patients and 12 controls. Total nucleic acids were extracted with MBs. Sequencing allowed this group to study the IBD gut microbiome at the highest resolution of their functional potential. In Schoenfelder's research [165], mammalian gene expression control was learned through high-throughput sequencing. High-throughput sequencing has also helped us understand the correlation between human genetic diseases and the identification of underlying disease genes.

To increase throughput for NGS, MNPs are widely used to process samples. Wu et al. [106] completed the preparation of 96-well plate samples with MNPs, meeting the needs of high-throughput sample preparation. Baker [166] prepared NGS libraries for constructing CFTR gene amplicon library using MiSeqDx IUO CF analysis reagent (Illumina), and used MBs for normalizing the libraries prior to pooling. The libraries were sequenced and were screened for neonatal CF. Hertz [167] uses MNPs and the Illumina MiSeq platform to examine pathogenic mutation genes related to sudden infant death syndrome.

Franasiak [168] sequenced 16S ribosome subunits of endometrial microflora during embryo transfer; Kostareva [169] analyzed 24 cases of idiopathic restrictive cardiomyopathy including 108 cardiomyopathy and arrhythmia related genes; Kou [170] carried out sequencing experiments on genes related to simulated samples in order to detect low abundance bladder cancer cells carrying a large number of mutations from urine;. Fisher [171] conducted clinical tests on somatic cell variations of nonsmall cell lung cancer, melanoma and gastrointestinal malignant tumors; Weimer [172] put forward human leukocyte antigen typing and sequencing which improved the overall survival rate of patients after hematopoietic stem cell transplantation; He [173] used the technology to improve the screening of thalassemia carriers among premarital adults in high-prevalence population; Operario [174] used amplicons to test the drug sensitivity of Mycobacterium tuberculosis; Dirani [175] uses next generation sequencing technology to genotype hepatitis $\mathrm{C}$ virus for clinical treatment, which is one of the major causes of liver-related death; Arias [176] tests HIV virus in humans through NGS and monitors drug resistance mutation, providing information on low-frequency drug resistance mutation and virus distribution in blood, so as to make sustainable response to treatment and better disease management. All of these researchers used MBs or MNPs for library preparation for NGS.

In nucleic acid detection, the traditional method of extracting and detecting nucleic acid has lower efficiency, complex protocols, expensive instrumentation and requires highly skilled staff. Therefore, the automation of experiments has attracted great attention of researchers. Using magnetic particles to develop automatic nucleic acid detection technology [177], greatly simplifies the experimental process and improves the experimental efficiency and accuracy.

Chen [178] developed a nucleic acid separation and purification instrument using MNPs, including three modules of temperature control, up-and-down movement and computer software, which are used in the whole process of automated extraction of nucleic acid from Escherichia coli O157: H7 for rapid screening of foodborne pathogens. Similarly, Ali designed a virus nucleic acid extraction scheme. The semi-automatic system is used to detect hepatitis B virus and hepatitis C virus simultaneously. Chen [107] designed the scheme of nucleic acid purification technology and its application on the basis of automatic extraction of nucleic acid, and then isolated and purified the sample of hepatocellular carcinoma, and obtained high-yield and high-purity nucleic acid through experiments. After automation is realized, Wang's [179] proposal can process multiple samples at the same time for multi-channel detection, with simple operation and greatly improved detection efficiency.

With the deepening of research, Chen [130] proposed a POCT system using MNPs that automated real-time testing for pathogens. Automated nucleic acid extraction had a higher repeatability and performed better when compared to manual testing. In recent years, many researchers such as Verigene (Nanosphere, Northbrook, US), iCubate2.0 (iCubate, Huntsville, US) and Rheonix (Rheonix, Ithaca, US) have used gene chips as detection tools and integrated microarrays into automated diagnostic equipment [180-183]. With the help of MNPs, these devices can automatically amplify, hybridize and detect gene targets.

\section{Other applications}

Liu [184] used MNPs to develop a new method using ligation-dependent PCR, and CL detection technique for quantitative analysis of copy number polymorphisms; however, this method needs improvement for both stability and repeatability. Hoan [185] used Raman Scattering 
for their study. A sandwich hybridization with MBs was used for nucleic acid detection [186, 187] with target sequences and ultra-bright SERS nanorods, while also identifying SNPs. The detection scheme includes sandwich hybridization of MBs bound to the capture probe, target sequences, and ultra-bright SERS nanorods bound to the report probe. After hybridization, the sandwich probe is concentrated at the detection focus controlled by the magnetic system for SERS measurement. Li [188] proposed a new signal amplification strategy for double detection of MEG3 specific sequences using MNPs. This method was able to detect DPV values of Fc and MB as low as $1 \mathrm{fM}$ to $100 \mathrm{pM}$. Genetic sensors have high selectivity and repeatability and have the potential to be a powerful tool for multiple quantitative analysis in early clinical diagnosis.

In Amini's research [189], two kinds of NPs were designed and utilized. The first kind was AuNPs wrapped by probe 1 and bio-barcoded DNA. The second kind was MNPs wrapped by probe 2 . The two kinds of functionalized NPs were mixed, and then gDNA was added into the solution to react, forming MNP-probe2-genomic DNAprobe1-AuNPs-bio-barcode DNA complex, washing out unreacted impurities. Then DTT was used to release the bio-barcode DNA, and fluorescence spectrophotometry was used to analyze the supernatant containing the biobarcode DNA. Researchers used this method to detect Staphylococcus aureus.

He [190] proposed a method for detecting circulating miR-142-3p in human serum by using functionalized MNPs. MNPs were used as the capture nanoprobes, and poly-HRP were used as the signal amplification probes. HRP labeled DNA H1 and H2-1 self-assembled to form poly-HRP. Streptophilin-modified MNPs were added to the lysate, with biotin-labeled capture genes attached to its surface, poly-HRP probe and auxiliary DNA were added. After hybridization, the CL signals were significantly amplified. MiR-142-3p of human serum sample is taken as an experimental sample to verify the feasibility of the method.

In order to diagnose neurodegenerative diseases of fragile X syndrome, Ren [191] loaded SA on MNPs, and then attached DNA modified with biotin as a capture probe. Target DNA hybridized with probe DNA and short report DNA labeled with carboxy-fluorescein (FSRDNA) to form complexes respectively. After the reaction was completed, FSR-DNA supernatant released was subjected to fluorescence detection through magnetic separation and de-hybridization. The method is simple to operate and provides great expectations for early diagnosis of the disease.

Tian [192] used DNA-based HCR and MNPs coupled with $\mathrm{Fe}_{3} \mathrm{O}_{4}$ to detect miRNA. Copper (II) complex was used as a small molecule enzyme mimic for miRNA signal while $\mathrm{Fe}_{3} \mathrm{O}_{4}$ were used as a separate target under magnetic field and was able to detect miRNA sensors. This method is expected to become a scheme to study next generation microRNA sensors, without the need of enzyme labeling or fluorophore labeling.

P53 is a human tumor suppressor gene, which is of great significance to human health. Therefore, Wang [193] established a CL method to detect the gene and used a new type of efficient luminescent material, 2',6'-dimethylcarbonylphenyl-10-sulfopropyl acridinium-9-carboxylate $4^{\prime}$-NHS ester (NSP-DMAE-NHS). The method comprises the following steps: firstly coating BSA on AuMNPs, and then connecting amino wildtype p53 genes. The functionalized MNPs were mixed with ssDNA-(NSP-DMAE-NHS) to hybridize. After the reaction is completed, unreacted impurities are removed by magnetic separation, then $\mathrm{HNO}_{3}+\mathrm{H}_{2} \mathrm{O}_{2}$ and $\mathrm{NaOH}$ are added to trigger $\mathrm{CL}$, and the luminous intensity is detected by a measuring system. The method can also be used for early diagnosis and treatment of cancer.

Wen [194] designed a convenient and quick method to capture and release hepatitis B virus DNA. Biotinylated captured DNA sequence of $\mathrm{HBV}$ was attached to MNPs coupled with SA, while the unwanted portion was blocked with biotin and bovine serum protein. Biotinylated target DNA sequence of HBV, hybridized and paired with the previously functionalized MNPs, the reaction compound is magnetically separated and then incubated with SA conjugated $\mathrm{CdSe} / \mathrm{ZnS}$ quantum dots, unreacted impurities are washed away, and supernatant is obtained after de-hybridization at high temperature for fluorescence determination. The method has been directly applied to the detection of serum samples, with good experimental results and practical application potential.

\section{Conclusion}

In this review, we have shown the application of MNPs in nucleic acid extraction, target substance enrichment and nucleic acid detection. We summarized the sequencing methods of DNA, SNP and methylation genes. In January 2003, the completion of human genome project led to several important findings related to the structure of the human genome $[195,196]$. SNP and methylation are included in this study's findings, which we reviewed in this paper. SNP and methylation are two forms of gene mutation, which are closely related to diseases [197-202]. In-depth research was conducted on SNP and methylation to find new courses for early detection of cancer [203-206]. The simultaneous detection of SNP and methylation at multiple sites by MNPs is conducive to the early diagnosis and prevention of cancer [207-210]. 
MNPs are widely used [211-215] because they are biocompatible and easily separated. The application of NPs is increasingly important in biotechnology. The MNPs used in this paper, like $\mathrm{Fe}_{2} \mathrm{O}_{3} / \mathrm{Fe}_{3} \mathrm{O}_{4}, \mathrm{Fe}_{3} \mathrm{O}_{4} / \mathrm{Au}, \mathrm{SiO}_{2} /$ $\mathrm{Fe}_{3} \mathrm{O}_{4}$, and $\mathrm{Fe}_{3} \mathrm{O}_{4}$ combined with PCR-assisted methods, radio-labeling techniques [216], HPLC [217], gel electrophoresis [218] and alternative approaches such as fluorescent, colorimetric, electrochemical and CL simplifies the experimental steps and improves the sensitivity and specificity of detecting DNA sequences, SNPs and methylation.

The birth of high-throughput sequencing technology is a milestone event in the field of genomics research [219225]. This technology by chip which read sequencing at millions of points at the same time makes the single base cost of nucleic acid sequencing increasingly lower than that of the first-generation sequencing technology. Taking human genome sequencing as an example, the human genome project carried out at the end of last century cost 3 billion US dollars to decode the human life code, while the second-generation sequencing has brought human genome sequencing into the era of meta-genomes. Such a low cost of single-base sequencing enables us to implement genome projects of more species and thus decrypt the genetic codes of genomes from more biological species. At the same time, among species that have completed genome sequencing, it is also possible to carry out large-scale whole genome resequencing [226, 227].

Genes are the biological genetic information base, which supports the basic structure and performance of life and stores all the information of life's race, such as blood type, gestation, growth, apoptosis and other processes [228-232]. The change of a base in a DNA sequence affects human health. Therefore, it is of great significance to develop rapid, real-time and accurate sequencing methods. Due to the complexity of human blood samples and the possibility of suffering from different diseases at the same time, there is an urgent need to develop a method to detect many different diseases in a single diagnosis [233-239]. The application of nano-magnetic material-based high-throughput sequencing continuously improves the sensitivity, selectivity and detection sample size, which meets the above requirements [240242]. The selection of magnetic nano-materials with large specific surface area and easy separation can be combined with various detection methods to obtain better sensitivity, selectivity and simultaneous detection of different sequences [243-253]. However, we still need further in-depth and detailed research in order to obtain a simpler and more flux sequencing method.

Although MNPs have many advantages, improvements are still needed in many aspects. Firstly, the magnetic separation performance of MNPs should be improved, thus meeting the application requirements in fast response and accurate positioning under external magnetic field [254, 255]. Secondly, MNPs stability could be improved, because it directly affects its application, for example, storage stability could be improved so that MNPs can be shipped and stored at room temperature [256]. Finally, preparation of MNPs with multi-function improves surface functionalization and ligand bonding efficiency [257].

MNPs combined with molecular diagnostic systems are used to develop fully-automatic and closed nucleic acid detection assays. If detection time and sensitivity can be improved, it will have great impact in clinical detection, biomedicine and other fields.

\section{Abbreviations}

NPs: Nanoparticles; MNPs: Magnetic nanoparticles; MRI: Magnetic resonance imaging; LOC: Lab-on-a-chip; AML: Acute myeloid leukemia; PCR: Polymerase chain reaction; MBs: Magnetic beads; SERS: Surface-enhanced Raman scattering; PAD: Paper-based analytical device; HCR: Hybridization chain reaction; SNP: Single nucleotide polymorphism; MS: Magnetic separation; MS-MRS: Magnetic relaxation switching; Pt/MNCs: Platinum-coated MNP clusters; AuMNPs: Gold magnetic nanoparticles; SA-MNPs: Streptavidin modified MNPs; LAMP: Loop-mediated isothermal amplification; AFP: Alpha-fetoprotein; CEA: Carcinoembryonic antigen; DA: Dopamine; CTC: Circulating tumor cells; MNCs: Magnetic nanoclusters; IMSs: Immune magnetosomes; FR: Folate receptor; OC: Ovarian cancer; GBS: Group B streptococci; gDNA: Genomic DNA; HRP: Horseradish peroxidase; CL: Chemiluminescence; GMBN: Gold magnetic bifunctional nanobeads; POCT: Point-of-care test; MagNBs: Magnetic nanobeads; Bbc-Au NP: NP labeled with hundreds of biological barcoded DNA; Oligo-MMP: DNA modified magnetic microparticle; MTHFR: Methylenetetrahydrofolate reductase; MEM-PCR: Magnetic enrichment-multiplex PCR: ARMS: Amplification refractory mutation system; LFA: Lateral flow analysis; Dam: Adenine methylation; Dam: Adenine methylation; APC: Adenomatous polyposis coli; MMPs: Magnetic microspheres; ssDNA: Single-stranded DNA; cf-mt: Cell-free mitochondrial; IBD: Inflammatory bowel disease; NGS: Highthroughput sequencing; FSR-DNA: Short report DNA labeled with carboxyfluorescein; NSP-DMAE-NHS: 2',6'-dimethylcarbonylphenyl-10-sulfopropyl acridinium-9-carboxylate $4^{\prime}$-NHS ester.

\section{Acknowledgements}

Congli Tang, Ziyu He, Hongmei Liu, Yuyue Xu, Hao Huang, Gaojian Yang, Ziqi Xiao, Hongna Liu, Zhu Chen, Hui Chen and Nongyue He are grateful to Hunan University of technology, China for support. Song Li and Yan Deng are grateful for the financial support provided by National Nature Science Foundation of China (NSFC). Song Li are grateful for the financial support provided by Education Department Outstanding Young Project of Hunan.

\section{Authors' contributions}

CLT wrote the manuscript, ZYH, HML, YYX, HH, GJY, and ZQX checked diferent sections of the manuscript. SL, HNL, YD, ZC, HC and NYH edited the manuscript. All authors read and approved the final manuscript.

\section{Funding}

This work was supported by the National Natural Science Foundation of China (Nos. 61971187, 61571187, 61871180), and Education Department Outstanding Young Project of Hunan Province (No. 18B299).

Availability of data and materials Not applicable.

Ethics approval and consent to participate Not applicable. 


\section{Consent for publication}

We have included five figures (Figs. 1, 2, 3, 4, 5) from previously published literature with required copyright permission from the copyright holder. We have mentioned this in the manuscript with proper citation.

\section{Competing interests}

The authors declare that they have no competing interests.

\section{Author details \\ ${ }^{1}$ Hunan Key Laboratory of Biomedical Nanomaterials and Devices, Hunan University of Technology, Zhuzhou 412007, China. ${ }^{2}$ State Key Laboratory of Bioelectronics, Southeast University, Nanjing 210096, China.}

Received: 3 December 2019 Accepted: 25 March 2020

Published online: 21 April 2020

\section{References}

1. Kang T, Li F, Baik S, Shao W, Ling D, Hyeon T. Surface design of magnetic nanoparticles forstimuli-responsive cancer imaging and therapy. Biomaterials. 2017;136:98-114.

2. Rao L, Bu LL, Meng QF, Cai B, Deng WW, Li A, et al. Antitumor plateletmimicking magnetic nanoparticles. Adv Funct Mater. 2017;27:6.

3. Karkan SF, Mohammadhosseini M, Panahi Y, Milani M, Zarghami N, Akbarzadeh A, et al. Magnetic nanoparticles in cancer diagnosis and treatment: a review. Artif Cell Nanomed B. 2017;45:1-5.

4. Dadfar SM, Roemhild K, Drude NI, Stillfried S, Knüchel R, Kiessling F, Lammers T. Iron oxide nanoparticles: diagnostic, therapeutic and theranostic applications. Adv Drug Deliver Rev. 2019;138:302-25.

5. Li D, Pan DS, Li SJ, Zhang ZD. Recent developments of rare-earth-free hard-magnetic materials. Sci China Phys Mech. 2016. https://doi. org/10.1007/s11433-015-5760-x.

6. Jamshaid T, Neto ETT, Eissa MM, Zine N, Kunita MH, El-Salhi AE, et al. Magnetic particles: from preparation to lab-on-a-chip, biosensors, microsystems and microfluidics applications. TrAC Trends Anal Chem. 2016;79:344-62.

7. Mohammed L, Gomaa HG, Ragab D, Zhu J. Magnetic nanoparticles for environmental and biomedical applications: a review. Particuology. 2017;30:1-14

8. Masud MK, Umer M, Hossain MSA, Yamauchi Y, Nguyen N-T, Shiddiky MJA. Nanoarchitecture frameworks for electrochemical miRNA detection. Trends Biochem Sci. 2019;44:433-52.

9. Rejeeth C, Pang X, Zhang R, Xu W, Sun X, Liu B, et al. Extraction, detection, and profiling of serum biomarkers using designed $\mathrm{Fe}_{3} \mathrm{O}_{4} @ \mathrm{SiO}_{2} @$ HA core-shell particles. Nano Res. 2018:11:68-79.

10. Shrivastava S, Lee WI, Lee NE. Culture-free, highly sensitive, quantitative detection of bacteria from minimally processed samples using fluorescence imaging by smartphone. Biosens Bioelectron. 2018;109:90-7.

11. Mosley O, Melling L, Tarn MD, Kemp C, Esfahani MMN, Pamme N, et al. Sample introduction interface for on-chip nucleic acid-based analysis of Helicobacter pylori from stool samples. Lab Chip. 2016;16:2108-15.

12. Brandão D, Liébana S, Pividori MI. Multiplexed detection of foodborne pathogens based on magnetic particles. N Biotechnol. 2015;32:511-20.

13. Tian B, Qiu Z, Ma J, Donolato M, Hansen MF, Svedlindh P, et al. Onparticle rolling circle amplification-based core-satellite magnetic superstructures for microRNA detection. ACS Appl Mater Interfaces. 2018;10:2957-64.

14. Hejazian M, Li W, Nguyen N. Lab on a chip for continuous-flow magnetic cell separation. Lab Chip. 2015;4:959-70.

15. Hedayatnasab Z, Abnisa F, Daud WMAW. Review on magnetic nanoparticles for magnetic nanofluid hyperthermia application. Mater Des. 2017;123:174-96.

16. Hou Y, Cai G, Zheng L, Lin J. A microfluidic signal-off biosensor for rapid and sensitive detection of Salmonella using magnetic separation and enzymatic catalysis. Food Control. 2019;103:186-93.

17. Oishi M, Sugiyama S. An efficient particle-based DNA circuit system: catalytic disassembly of DNA/PEG-modified gold nanoparticlemagnetic bead composites for colorimetric detection of miRNA. Small. 2016;12:5153-8.
18. Povedano E, Vargas E, Montiel VRV, Torrente-Rodríguez RM, Pedrero $M$, Barderas R, et al. Electrochemical affinity biosensors for fast detection of gene-specific methylations with no need for bisulfite and amplification treatments. Sci Rep. 2018;8:1-11.

19. Hernández-Neuta I, Pereiro I, Ahlford A, Ferraro D, Zhang Q, Viovy JL, et al. Microfluidic magnetic fluidized bed for DNA analysis in continuous flow mode. Biosens Bioelectron. 2018;102:531-9.

20. Liana AE, Marquis CP, Gunawan C, Gooding JJ, Amal R. T4 bacteriophage conjugated magnetic particles for E. coli capturing: Influence of bacteriophage loading, temperature and tryptone. Colloids Surf B Biointerfaces. 2017;151:47-57.

21. Abu-dief AM, Hamdan SK. Functionalization of magnetic nano particles: synthesis, characterization and their application in water purification. Am J Nanosci. 2016:2:26-40.

22. Ruiz-Valdepenas Montiel V, Povedano E, Vargas E, Torrente-Rodríguez RM, Pedrero M, Reviejo AJ, et al. Comparison of different strategies for the development of highly sensitive electrochemical nucleic acid biosensors using neither nanomaterials nor nucleic acid amplification. ACS Sensors. 2018;3:211-21.

23. Uliana CV, Peverari CR, Afonso AS, Cominetti MR, Faria RC. Fully disposable microfluidic electrochemical device for detection of estrogen receptor alpha breast cancer biomarker. Biosens Bioelectron. 2018;99:156-62.

24. Ali N, Rampazzo RDCP, Costa ADT, Krieger MA. Current nucleic acid extraction methods and their implications to point-of-care diagnostics. Biomed Res Int. 2017. https://doi.org/10.1155/2017/9306564.

25. Li T, Xu X, Zhang G, Lin R, Chen Y, Li C, et al. Nonamplification sandwich assay platform for sensitive nucleic acid detection based on AuNPs enumeration with the dark-field microscope. Anal Chem. 2016;88:4188-91.

26. Yang $X$, Zhou $X$, Zhu M, Xing D. Sensitive detection of Listeria monocytogenes based on highly efficient enrichment with vancomycinconjugated brush-like magnetic nano-platforms. Biosens Bioelectron. 2017;91:238-45.

27. Rodrigues NFM, Neto SY, Luz RDCS, Damos FS, Yamanaka H. Ultrasensitive determination of malathion using acetylcholinesterase immobilized on chitosan-functionalized magnetic iron nanoparticles. Biosensors. 2018;8:16.

28. Ali Z, Wang J, Mou X, Tang Y, Li T, Liang W, et al. Integration of nucleic acid extraction protocol with automated extractor for multiplex viral detection. J Nanosci Nanotechnol. 2017;17:862-70.

29. Borsa BA, Tuna BG, Hernandez FJ, Hernandez LI, Bayramoglu G, Arica MY, et al. Staphylococcus aureus detection in blood samples by silica nanoparticle-oligonucleotides conjugates. Biosens Bioelectron. 2016;86:27-32.

30. Xie L, Li T, Hu F, Jiang Q, Wang Q, Gan N. A novel microfluidic chip and antibody-aptamer based multianalysis method for simultaneous determination of several tumor markers with polymerization nicking reactions for homogenous signal amplification. Microchem J. 2019;147:454-62.

31. Carinelli S, Martí M, Alegret S, Pividori MI. Biomarker detection of global infectious diseases based on magnetic particles. N Biotechnol. 2015:32:521-32.

32. Guesmi R, Farah MAB, Kachouri A, Samet M. A novel chaos-based image encryption using DNA sequence operation and Secure Hash Algorithm SHA-2. Nonlinear Dyn. 2016;83:1123-36.

33. Qi Z, Redding S, Lee JY, Gibb B, Kwon Y, Niu H, et al. DNA sequence alignment by microhomology sampling during homologous recombination. Cell. 2015;160:856-69.

34. Owen JG, Charlop-Powers Z, Smith AG, Ternei MA, Calle PY, Reddy $B V B$, et al. Multiplexed metagenome mining using short DNA sequence tags facilitates targeted discovery of epoxyketone proteasome inhibitors. Proc Natl Acad Sci. 2015;112:4221-6.

35. Miska EA, Ferguson-smith AC. Transgenerational inheritance: models and mechanisms of non-DNA sequence-based inheritance. Science. 2016;354:778-82.

36. Lee D, Gorkin DU, Baker M, Strober BJ, Asoni AL, McCallion AS, et al. A method to predict the impact of regulatory variants from DNA sequence. Nat Genet. 2015;47:955-61. 
37. Indjeian VB, Kingman GA, Jones FC, Guenther CA, Grimwood J, Schmutz $J$, et al. Evolving new skeletal traits by cis-regulatory changes in bone morphogenetic proteins. Cell. 2016;164:45-56.

38. Lek M, Karczewski KJ, Minikel EV, Samocha KE, Banks E, Fennell T, et al. Analysis of protein-coding genetic variation in 60,706 humans. Nature 2016;536:285-91.

39. Lai S, Qin Y, Cowling BJ, Ren X, Wardrop NA, Gilbert M, et al. Global epidemiology of avian influenza A H5N1 virus infection in humans, 1997-2015: a systematic review of individual case data. Lancet Infect Dis. 2016;16:e108-18.

40. Langhanki L, Berger P, Treffon J, Catania F, Kahl BC, Mellmann A. In vivo competition and horizontal gene transfer among distinct Staphylococcus aureus lineages as major drivers for adaptational changes during long-term persistence in humans. BMC Microbiol. 2018;18:152.

41. Berg V, Lummaa V, Rickard IJ, Silventoinen K, Kaprio J, Jokela M. Genetic associations between personality traits and lifetime reproductive success in humans. Behav Genet. 2016;46:742-53.

42. Xu H, Zhang S, Ouyang C, Wang Z, Wu D, Liu Y, et al. DNA nanostructures from palindromic rolling circle amplification for the fluorescent detection of cancer-related microRNAs. Talanta. 2019;192:175-81.

43. Papaemmanuil E, Gerstung M, Bullinger L, Gaidzik VI, Paschka P, Roberts ND, et al. Genomic classification and prognosis in acute myeloid leukemia. N Engl J Med. 2016;374:2209-21.

44. Harris LN, Ismaila N, McShane LM, Andre F, Collyar DE, Gonzalez-Angulo $A M$, et al. Use of biomarkers to guide decisions on adjuvant systemic therapy for women with early-stage invasive breast cancer: American Society of clinical Oncology clinical practice guideline. J Clin Oncol. 2016;34:1134-50.

45. Travis WD, Brambilla E, Nicholson AG, Yatabe Y, Austin JHM, Beasley MB, et al. The 2015 World Health Organization classification of lung tumors: impact of genetic, clinical and radiologic advances since the 2004 classification. J Thorac Oncol. 2015;10:1243-60.

46. Orfanelli U, Jachetti E, Chiacchiera F, Grioni M, Brambilla P, Briganti A, et al. Antisense transcription at the TRPM2 locus as a novel prognostic marker and therapeutic target in prostate cancer. Oncogene. 2014;34:2094-102.

47. Pajtler KW, Mack SC, Ramaswamy V, Smith CA, Witt H, Smith A, et al. The current consensus on the clinical management of intracranial ependymoma and its distinct molecular variants. Acta Neuropathol. 2017:133:5-12.

48. Szász AM, Lánczky A, Nagy Á, Förster S, Hark K, Green JE, et al. Crossvalidation of survival associated biomarkers in gastric cancer using transcriptomic data of 1,065 patients. Oncotarget. 2016;7:49322-33.

49. Von Minckwitz G, Huang CS, Mano MS, Loibl S, Mamounas EP, Untch M, et al. Trastuzumab emtansine for residual invasive HER2-positive breast cancer. N Engl J Med. 2019;380:617-28.

50. Khaled WT, Lee SC, Stingl J, Chen X, Ali HR, Rueda OM, et al. BCL11A is a triple-negative breast cancer gene with critical functions in stem and progenitor cells. Nat Commun. 2015;6:1-10.

51. Sparano JA, Gray RJ, Makower DF, Pritchard Kl, Albain KS, Hayes DF, et al. Prospective validation of a 21-gene expression assay in breast cancer. N Engl J Med. 2015;373:2005-14.

52. Trail PA, Dubowchik GM, Lowinger TB. Antibody drug conjugates for treatment of breast cancer: novel targets and diverse approaches in ADC design. Pharmacol Ther. 2018;181:126-42.

53. Tischkowitz M, Ph D, Tavtigian SV, Ph D, Nathanson KL, Devilee P, et al. Gene-panel sequencing and the prediction of breast-cancer risk. N Engl J Med. 2015;372:2243-57.

54. Yurgelun MB, Chittenden AB, Morales-Oyarvide V, Rubinson DA, Dunne RF, Kozak MM, et al. Germline cancer susceptibility gene variants, somatic second hits, and survival outcomes in patients with resected pancreatic cancer. Genet Med. 2019;21:213-23.

55. Berenstein R. Class III receptor tyrosine kinases in acute leukemiabiological functions and modern laboratory analysis. Biomark Insights. 2015;2015:1-14

56. Kayser S, Levis MJ. Clinical implications of molecular markers in acute myeloid leukemia. Eur J Haematol. 2019;102:20-35.

57. Amaar YG, Reeves ME. Research paper RASSF1C regulates miR-33a and EMT marker gene expression in lung cancer cells. Oncotarget. 2019;10:123-32.
58. Zeng Z, Bo H, Gong Z, Lian Y, Li X, Li X, et al. AFAP1-AS1, a long noncoding RNA upregulated in lung cancer and promotes invasion and metastasis. Tumor Biol. 2016;37:729-37.

59. George J, Lim JS, Jang SJ, Cun Y, Ozretia L, Kong G, et al. Comprehensive genomic profiles of small cell lung cancer. Nature. 2015;524:47-53.

60. Xie RL, Jang YJ, Xing L, Zhang BF, Wang FZ, Cui PF, et al. A novel potential biocompatible hyperbranched polyspermine for efficient lung cancer gene therapy. Int J Pharm. 2015;478:19-30.

61. Yang Y, Meng H, Peng Q, Yang X, Gan R, Zhao L, et al. Downregulation of microRNA-21 expression restrains non-small cell lung cancer cell proliferation and migration through upregulation of programmed cell death 4. Cancer Gene Ther. 2015;22:23-9.

62. Dagogo-Jack I, Martinez P, Yeap BY, Ambrogio C, Ferris LA, Lydon C, et al. Impact of BRAF mutation class on disease characteristics and clinical outcomes in BRAF-mutant lung cancer. Clin Cancer Res. 2019;25:158-65.

63. Kaznatcheev A, Peacock J, Basanta D, Marusyk A, Scott JG. Fibroblasts and alectinib switch the evolutionary games played by non-small cell lung cancer. Nat Ecol Evol. 2019;3:450-6.

64. Lee CK, Wu YL, Ding PN, Lord SJ, Inoue A, Zhou C, et al. Impact of specific Epidermal Growth Factor Receptor (EGFR) mutations and clinical characteristics on outcomes after treatment with EGFR tyrosine kinase inhibitors versus chemotherapy in EGFR-mutant lung cancer: a metaanalysis. J Clin Oncol. 2015;33:1958-65.

65. Shi Y, Au JSK, Thongprasert S, Srinivasan S, Tsai CM, Khoa MT, et al. A prospective, molecular epidemiology study of EGFR mutations in Asian patients with advanced non-small-cell lung cancer of adenocarcinoma histology (PIONEER). J Thorac Oncol. 2014;9:154-62.

66. Rocco D, Battiloro C, Della Gravara L, Gridelli C. Safety and tolerability of anaplastic lymphoma kinase inhibitors in non-small-cell lung cancer. Drug Saf. 2019:42:199-209.

67. Barati Bagherabad M, Afzaljavan F, ShahidSales S, Hassanian SM, Avan A. Targeted therapies in pancreatic cancer: promises and failures. J Cell Biochem. 2019;120:2726-41.

68. Gatalica Z, Xiu J, Swensen J, Vranic S. Molecular characterization of cancers with NTRK gene fusions. Mod Pathol. 2019;32:147-53.

69. Lin JJ, Chin E, Yeap BY, Ferris LA, Kamesan V, Lennes IT, et al. Increased hepatotoxicity associated with sequential immune checkpoint inhibitor and crizotinib therapy in patients with non-small cell lung cancer. J Thorac Oncol. 2019;14:135-40.

70. Eichner LJ, Brun SN, Herzig S, Young NP, Curtis SD, Shackelford DB, et al. Genetic analysis reveals AMPK is required to support tumor growth in murine kras-dependent lung cancer models. Cell Metab. 2019;29:285-302.

71. Schuler M, Wu YL, Hirsh V, O'Byrne K, Yamamoto N, MokT, et al. First-line afatinib versus chemotherapy in patients with non-small cell lung cancer and common epidermal growth factor receptor gene mutations and brain metastases. J Thorac Oncol. 2016;1 1:380-90.

72. Pociot F, Lernmark Å. Genetic risk factors for type 1 diabetes. Lancet. 2016;387:2331-9.

73. Khardori R. Type 1 diabetes mellitus type 1 diabetes mellitus. Goldman's Cecil Med. 1989;3:287-304.

74. Thakore PI, Gersbach CA. Genome engineering for therapeutic applications. In: Transl. Gene Ther. to Clin. 2015. p 27-43.

75. Chaytor NS, Barbosa-Leiker C, Ryan CM, Germine LT, Hirsch IB, Weinstock RS. Clinically significant cognitive impairment in older adults with type 1 diabetes. J Diabetes Complicat. 2019;33:91-7.

76. Schmidt AF, Swerdlow DI, Holmes MV, Patel RS, Fairhurst-Hunter Z, Lyall DM, et al. PCSK9 genetic variants and risk of type 2 diabetes: a mendelian randomisation study. Lancet Diabetes Endocrinol. 2017:5:97-105.

77. Soriano-Tárraga C, Jiménez-Conde J, Giralt-Steinhauer E, Mola-Caminal M, Vivanco-Hidalgo RM, Ois A, et al. Epigenome-wide association study identifies TXNIP gene associated with type 2 diabetes mellitus and sustained hyperglycemia. Hum Mol Genet. 2016;25:609-19.

78. Dos Santos Nunes MK, Silva AS, De Queiroga Evangelista IW, Filho JM, Gomes CNAP, Do Nascimento RAF, et al. Hypermethylation in the promoter of the MTHFR gene is associated with diabetic complications and biochemical indicators. Diabetol Metab Syndr. 2017;9:1-9.

79. Swerdlow DI, Preiss D, Kuchenbaecker KB, Holmes MV, Engmann JEL, Shah T, et al. HMG-coenzyme A reductase inhibition, type 2 diabetes, 
and bodyweight: evidence from genetic analysis and randomised trials. Lancet. 2015;385:351-61.

80. Vats P, Sagar N, Singh TP, Banerjee M. Association of Superoxide dismutases (SOD1 and SOD2) and Glutathione peroxidase 1 (GPX1) gene polymorphisms with type 2 diabetes mellitus. Free Radic Res. 2015;49:17-24.

81. Besseling J, Kastelein JJP, Defesche JC, Hutten BA, Hovingh GK. Association between familial hypercholesterolemia and prevalence of type 2 diabetes mellitus. JAMA J Am Med Assoc. 2015:313:1029-36.

82. Schmidt J, Gong S, Marafioti T, Mankel B, Gonzalez-farre B, Balagu O, et al. Genome-wide analysis of pediatric-type follicular lymphoma reveals low genetic complexity and recurrent alterations of TNFRSF14 gene. Blood. 2016;128:1101-12.

83. Sabetta R, Gargiulo M, Accardo M, Marino FZ, Franco R. Anaplastic lymphoma tyrosine kinase oncogene in human cancer: gene aberrations, methods of detection and therapeutic potential. Transl Med. 2017;1:86-91.

84. Jeon J, Du M, Schoen RE, Hoffmeister M, Newcomb PA, Berndt SI, et al. Determining risk of colorectal cancer and starting age of screening based on lifestyle, environmental, and genetic factors. Gastroenterology. 2018;154:2152-64.

85. Ruff S, Curtin B, Quezado M, Heller T, Koh C, Steinberg SM, et al. Evaluation of confocal endoscopic microscopy for detection of early-stage gastric cancer in hereditary diffuse gastric cancer (HDGC) syndrome. J Gastro Oncol. 2019;10:407-11.

86. Naccarati A, Rosa F, Vymetalkova V, Barone E, Di Gaetano C, Novotny J, et al. Double-strand break repair and colorectal cancer: gene variants within $3^{\prime}$ UTRs and microRNAs binding as modulators of cancer risk and clinical outcome. Oncotarget. 2016;7:23156-69.

87. Arch V, Müller MF, Ibrahim AEK, Arends MJ. Molecular pathological classification of colorectal cancer. Virchows Arch. 2016:469:125-34.

88. Robles Al, Traverso G, Zhang M, Roberts NJ, Khan A, Joseph C, et al. Whole-exome sequencing analyses of inflammatory bowel diseaseassociated colorectal cancers. Gastroenterology. 2016;150:931-43.

89. Robinson D, Van Allen EM, Sawyers CL, Chinnaiyan AM, Robinson D, Van Allen EM, et al. Integrative clinical genomics of advanced prostate resource integrative clinical genomics of advanced prostate cancer. Cell. 2015;161:1215-28.

90. Lee AR, Dong X, Gan Y, Xie N, Ramnarine VR, Lovnicki JM. Alternative RNA splicing of the GIT1 gene is associated with neuroendocrine prostate cancer. Cancer Sci. 2019;110:245-55.

91. Sehrawat A, Gao L, Wang Y, Bankhead A, Mcweeney SK, King CJ, et al. LSD1 activates a lethal prostate cancer gene network independently of its demethylase function. Proc Natl Acad Sci USA. 2018;115:4179-88.

92. Bernard V, Kim DU, San Lucas FA, Castillo J, Allenson K, Mulu FC, et al. Circulating nucleic acids are associated with outcomes of patients with pancreatic cancer. Gastroenterology. 2019;156:108-18.

93. Chen H, Wu Y, Fang Y, Liao P, Zhao K, Deng Y, et al. Integrated and automated, sample-into result-out, system for nanotechnologybased detection of infectious pathogens. Nanosci Nanotechnol Lett. 2018:10:1423-8.

94. Tang S, Gu Y, Lu H, Dong H, Zhang K, Dai W, et al. Highly-sensitive microRNA detection based on bio-bar-code assay and catalytic hairpin assembly two-stage amplification. Anal Chim Acta. 2018;1004:1-9.

95. Keshavarz M, Ra H. Recent trends in electrochemical microRNA biosensors for early detection of cancer. RSC Adv. 2015;5:35651-60.

96. Ngo HT, Wang H, Fales AM, Vo-dinh T. Plasmonic SERS biosensing nanochips for DNA detection. Anal Bioanal Chem. 2016;408:1773-81.

97. Tiwari AP, Satvekar RK, Rohiwal SS, Karande VA, Raut AV, Patil PG, et al. Magneto-separation of genomic deoxyribose nucleic acid using $\mathrm{pH}$ responsive $\mathrm{Fe}_{3} \mathrm{O}_{4} @$ silica@chitosan nanoparticles in biological samples. RSC Adv. 2015:5:8463-70.

98. Su S, Chen Y, Li K, Fang Y, Wang C, et al. Electrohydrodynamically enhanced drying droplets for concentration of Salmonella bacteria prior to their detections using antibody-functionalized SERS-reporter submicron beads. Sensor Actuat B Chem. 2019;283:384-9.

99. Wang J, Ali Z, Wang N, Liang W, Liu H, Li F, et al. Simultaneous extraction of DNA and RNA from Escherichia coli BL 21 based on silica-coated magnetic nanoparticles. Sci China Chem. 2015;58:1774-8.

100. Stray J, Zimmermann B. Isolation of cell-free DNA from maternal plasma. Methods Mol Biol. 2019:1885:309-23.
101. Mauk MG, Song J, Liu C, Bau HH. Simple approaches to minimallyinstrumented, microfluidic-based point-of-care Nucleic Acid Amplification Tests. Biosensors. 2018;8:17.

102. Pang Y, Wang C, Wang J, Sun Z, Xiao R, Wang S. Fe3O4@Ag magnetic nanoparticles for microRNA capture and duplex-specific nuclease signal amplification based SERS detection in cancer cells. Biosens Bioelectron. 2016:79:574-80

103. Chen W, Fang X, Li H, Cao H, Kong J. DNA-mediated inhibition of peroxidase-like activities on platinum nanoparticles for simple and rapid colorimetric detection of nucleic acids. Biosens Bioelectron. 2017:94:169-75.

104. Wang J, Ali Z, Si J, Wang N, He N, Li Z. Simultaneous extraction of DNA and RNA from hepatocellular carcinoma (Hep G2) based on silica-coated magnetic nanoparticles. J Nanosci Nanotechnol. 2017;17:802-6.

105. Li B, Mou X, Chen Z, Chen H, Deng Y, Li S, et al. The development of a rapid high-quality universal nucleic acid extraction kit based on magnetic separation. Sci China Chem. 2017;60:1602-8.

106. Wu Y, Chen H, Chen Z, Nie L, Liu B, He N. Multifunctional device for nucleic acid extraction based on magnetic separation and its co-working with liquid handling system for high throughput sample preparation. J Nanosci Nanotechnol. 2016;16:6919-24.

107. Chen Z, Wu Y, Chen H, Mou X, Chen Z, Deng Y, et al. Design and application of automatic and rapid nucleic acid extractor using magnetic nanoparticles. J Nanosci Nanotechnol. 2016;16:6998-7004.

108. Tavallaie R, McCarroll J, Le Grand M, Ariotti N, Schuhmann W, Bakker $E$, et al. Nucleic acid hybridization on an electrically reconfigurable network of gold-coated magnetic nanoparticles enables microRNA detection in blood. Nat Nanotechnol. 2018;13:1066-71.

109. Zhu M, Liu W, Liu H, Liao Y, Wei J, Zhou X, et al. Construction of $\mathrm{Fe}_{3} \mathrm{O}_{4} /$ vancomycin/PEG magnetic nanocarrier for highly efficient pathogens enrichment and gene-sensing. ACS Appl Mater Interfaces. 2015;7:12873-81

110. Chen $Y$, Xianyu Y, Wang $Y$, Zhang $X$, Cha R, Sun J, et al. One-step detection of pathogens and viruses: combining magnetic relaxation switching and magnetic separation. ACS Nano. 2015;9:3184-91.

111. Kwon D, Lee S, Ahn MM, Kang IS, Park KH, Jeon S. Colorimetric detection of pathogenic bacteria using platinum-coated magnetic nanoparticle clusters and magnetophoretic chromatography. Anal Chim Acta. 2015;883:61-6.

112. Wang J, Wu X, Wang C, Rong Z, Ding H, Li H, et al. Facile synthesis of au-coated magnetic nanoparticles and their application in bacteria detection via a SERS method. ACS Appl Mater Interfaces. 2016;8:19958-67.

113. Cheng D, Yu M, Fu F, Han W, Li G, Xie J, et al. Dual recognition strategy for specific and sensitive detection of bacteria using aptamer-coated magnetic beads and antibiotic-capped gold nanoclusters. Anal Chem. 2016;88:820-5.

114. Liu H, Dong H, Chen Z, Lin L, Chen H, Li S, et al. Magnetic nanoparticles enhanced microarray detection of multiple foodborne pathogens. $J$ Biomed Nanotechnol. 2017;13:1333-43.

115. Wang J, Wu H, Yang Y, Yan R, Zhao Y, Wang Y, et al. Bacterial speciesidentifiable magnetic nanosystems for early sepsis diagnosis and extracorporeal photodynamic blood disinfection. Nanoscale. 2018;10:132-41.

116. Kaur A, Kapil A, Elangovan R, Jha S, Kalyanasundaram D. Highly-sensitive detection of Salmonella typhi in clinical blood samples by magnetic nanoparticle-based enrichment and in situ measurement of isothermal amplification of nucleic acids. PLoS ONE. 2018;13:1-14.

117. Wang D, Gan N, Zhang H, Li T, Qiao L, Cao Y, et al. Simultaneous electrochemical immunoassay using graphene-Au grafted recombinant apoferritin-encoded metallic labels as signal tags and dual-template magnetic molecular imprinted polymer as capture probes. Biosens Bioelectron. 2015;65:78-82.

118. Zhao W, Cheng R, Miller JR, Mao L. Label-free microfluidic manipulation of particles and cells in magnetic liquids. Adv Funct Mater. 2016;26:3916-32.

119. Hong W, Lee S, Chang HJ, Lee ES, Cho Y. Multifunctional magnetic nanowires: a novel breakthrough for ultrasensitive detection and isolation of rare cancer cells from non-metastatic early breast cancer patients using small volumes of blood. Biomaterials. 2016;106:78-86. 
120. Xiong K, Wei W, Jin Y, Wang S, Zhao D, Wang S, et al. Biomimetic immuno-magnetosomes for high-performance enrichment of circulating tumor cells. Adv Mater. 2016;28:7929-35.

121. Liu W, Nie L, Li F, Aguilar ZP, Xu H, Xiong Y, et al. Folic acid conjugated magnetic iron oxide nanoparticles for nondestructive separation and detection of ovarian cancer cells from whole blood. Biomater Sci. 2016:4:159-66.

122. Parham NJ, Picard FJ, Peytavi R, Gagnon M, Seyrig G, Gagné PA, et al. Specific magnetic bead-based capture of genomic DNA from clinical samples: application to the detection of group B streptococci in vaginal/anal swabs. Clin Chem. 2007;53:1570-6.

123. Zeinhom MMA, Wang Y, Sheng L, Du D, Li L, Zhu MJ, et al. Smart phone based immunosensor coupled with nanoflower signal amplification for rapid detection of Salmonella enteritidis in milk, cheese and water. Sensor Actuat B Chem. 2018;261:75-82.

124. Zhuang L, Ji Y, Tian P, Wang K, Kou C, Gu N, et al. Polymerase chain reaction combined with fluorescent lateral flow immunoassay based on magnetic purification for rapid detection of canine parvovirus 2. BMC Vet Res. 2019;15:1-13.

125. Wu Z, Zeng T, Guo WJ, Bai YY, Pang DW, Zhang ZL. Digital single virus immunoassay for ultrasensitive multiplex avian influenza virus detection based on fluorescent magnetic multifunctional nanospheres. ACS Appl Mater Interfaces. 2019;11:5762-70.

126. Ali Z, Wang J, Tang Y, Liu B, He N, Li Z. Simultaneous detection of multiple viruses based on chemiluminescence and magnetic separation. Biomater Sci. 2017;5:57-66.

127. Cortina ME, Melli LJ, Roberti M, Mass M, Longinotti G, Tropea S, et al. Electrochemical magnetic microbeads-based biosensor for pointof-care serodiagnosis of infectious diseases. Biosens Bioelectron. 2016;80:24-33.

128. Xia S, Yu Z, Liu D, Xu C, Lai W. Developing a novel immunochromatographic test strip with gold magnetic bifunctional nanobeads (GMBN) for efficient detection of Salmonella choleraesuis in milk. Food Control. 2016;59:507-12.

129. DuVall JA, Cabaniss ST, Angotti ML, Moore JH, Abhyankar M, Shukla $N$, et al. Rapid detection of: clostridium difficile via magnetic bead aggregation in cost-effective polyester microdevices with cell phone image analysis. Analyst. 2016;141:5637-45.

130. Chen H, Wu Y, Chen Z, Hu Z, Fang Y, Liao P, et al. Performance evaluation of a novel sample in-answer out (SIAO) system based on magnetic nanoparticles. J Biomed Nanotechnol. 2017;13:1619-30.

131. Andreadou M, Liandris E, Gazouli M, Mataragka A, Tachtsidis I, Goutas $\mathrm{N}$, et al. Detection of Leishmania-specific DNA and surface antigens using a combination of functionalized magnetic beads and cadmium selenite quantum dots. J Microbiol Methods. 2016;123:62-7.

132. Oh S, Kim J, Tran VT, Lee DK, Ahmed SR, Hong JC, et al. Magnetic nanozyme-linked immunosorbent assay for ultrasensitive influenza A virus detection. ACS Appl Mater Interfaces. 2018;10:12534-43.

133. Feng $N$, Zhou $Y$, Fan $Y, B i$ Y, Yang R, Zhou Y, et al. Yersinia pestis detection by loop-mediated isothermal amplification combined with magnetic bead capture of DNA. Braz J Microbiol. 2018;49:128-37.

134. Fang Y, Wu Y, Liao P, Chen Z, Chen H, Yu J, et al. Design and application of a high-throughput sample processing module based on magnetic beads. Nanosci Nanotechnol Lett. 2018;10:320-8.

135. Kachuri L, Amos Cl, Mckay JD, Johansson M, Vineis P, Bueno-de-mesquita HB, et al. Common variants at the CHEK2 gene locus and risk of epithelial ovarian cancer. Carcinogenesis. 2015;36:1341-53.

136. Karczewski KJ, Snyder MP. Integrative omics for health and disease. Nat Rev Genet. 2018;19:299-310.

137. Obeidat M, Hao K, Bossé Y, Nickle DC, Nie Y, Postma DS, et al. Molecular mechanisms underlying variations in lung function: a systems genetics analysis. Lancet Respir Med. 2015;3:782-95.

138. Lapitan LDS, Guo Y, Zhou D. Nano-enabled bioanalytical approaches to ultrasensitive detection of low abundance single nucleotide polymorphisms. Analyst. 2015;140:3872-87.

139. Ngo HT, Gandra N, Fales AM, Taylor SM, Vo-Dinh T. Sensitive DNA detection and SNP discrimination using ultrabright SERS nanorattles and magnetic beads for malaria diagnostics. Biosens Bioelectron. 2016;81:8-14
140. Liu H, Li S, Wang Z, Ji M, Nie L, He N. High-throughput SNP genotyping based on solid-phase PCR on magnetic nanoparticles with dual-color hybridization. J Biotechnol. 2007;131:217-22

141. Wang Z, Guo H, Yu Y, He N. Synthesis and characterization of a novel magnetic carrier with its composition of $\mathrm{Fe}_{3} \mathrm{O}_{4} /$ carbon using hydrothermal reaction. J Magn Magn Mater. 2006;302:397-404.

142. Li S, Liu H, Wang Z, Hou P, Guo Y, He Q, et al. Magnetic-particles-based high-throughput genotyping method with dual-color fluorescence hybridization. Anal Biochem. 2006;359:277-9.

143. Tang Y, Ali Z, Dai J, Liu X, Wu Y, Chen Z, et al. Single-nucleotide polymorphism genotyping of exoS in pseudomonas aeruginosa using dualcolor fluorescence hybridization and magnetic separation. J Biomed Nanotechnol. 2018:14:206-14.

144. Li S, Liu H, Jia Y, Deng Y, Zhang L, Lu Z, et al. A novel SNPs detection method based on gold magnetic nanoparticles array and single base extension. Theranostics. 2012;2:967-75.

145. Li S, Liu H, Jia Y, Mou X, Deng Y, Lin L, et al. An automatic high-throughput single nucleotide polymorphism genotyping approach based on universal tagged arrays and magnetic nanoparticles. J Biomed Nanotechnol. 2013;9:689-98.

146. Shen W, Deng H, Gao Z. Gold nanoparticle-enabled real-time ligation chain reaction for ultrasensitive detection of DNA. J Am Chem Soc. 2012;134:14678-81.

147. Min CY, Wu LQ, Qian TT, Ain NU, Liu WJ, Wu XN, et al. Typing and determination of SNP functional gene based on highly selective and signal-amplified fluorescence double-probe with the help of ExollI nuclease and magnetic bead. J Pharmaceut Biomed. 2020. https://doi. org/10.1016/j.jpba.2019.112917.

148. Yan XH, Zhang SN, Liang JP, Cai Y, Zhu JL, Zhang C, et al. A PCR-lateral flow assay system based on gold magnetic nanoparticles for CYP2C19 genotyping and its clinical applications. Artif Cell Nanomed B. 2019;47:636-43.

149. Hui W, Zhang S, Zhang C, Wan Y, Zhu J, Zhao G, et al. A novel lateral flow assay based on GoldMag nanoparticles and its clinical applications for genotyping of MTHFR C677T polymorphisms. Nanoscale. 2016:8:3579-87.

150. Liu X, Zhang C, Liu K, Wang H, Lu C, Li H, et al. Multiple SNPs detection based on lateral flow assay for phenylketonuria diagnostic. Anal Chem. 2018;90:3430-6.

151. Valinluck V, Tsai HH, Rogstad DK, Burdzy A, Bird A, Sowers LC. Oxidative damage to methyl-CpG sequences inhibits the binding of the methylCpG binding domain (MBD) of methyl-CpG binding protein 2 (MeCP2). Nucleic Acids Res. 2004;32:4100-8.

152. Crujeiras AB, Morcillo S, Diaz-Lagares A, Sandoval J, Castellano-Castillo $D$, Torres $E$, et al. Identification of an episignature of human colorectal cancer associated with obesity by genome-wide DNA methylation analysis. Int J Obes. 2019;43:176-88.

153. Gebhard C, Glatz D, Schwarzfischer L, Wimmer J, Stasik S, Nuetzel M, et al. Profiling of aberrant DNA methylation in acute myeloid leukemia reveals subclasses of CG-rich regions with epigenetic or genetic association. Leukemia. 2019;33:26-36.

154. Schübeler D. Function and information content of DNA methylation. Nature. 2015:517:321-6.

155. Hong SR, Shin KJ, Jung SE, Lee EH, Lee HY. Platform-independent models for age prediction using DNA methylation data. Forensic Sci Int Genet. 2019;38:39-47.

156. Smith AR, Smith RG, Burrage J, Troakes C, Al-Sarraj S, Kalaria RN, et al. A cross-brain regions study of ANK1 DNA methylation in different neurodegenerative diseases. Neurobiol Aging. 2019;74:70-6.

157. Lacey M, Baribault C, Ehrlich KC, Ehrlich M. Atherosclerosis-associated differentially methylated regions can reflect the disease phenotype and are often at enhancers. Atherosclerosis. 2019;280:183-91.

158. Liu T, Zhao J, Zhang D, Li G. Novel method to detect DNA methylation using gold nanoparticles coupled with enzyme-linkage reactions. Anal Chem. 2010;82:229-33.

159. Ge C, Fang Z, Chen J, Liu J, Lu X, Zeng L. A simple colorimetric detection of DNA methylation. Analyst. 2012;137:2032-5.

160. Bi S, Zhao T, Luo B, Zhu JJ. Hybridization chain reaction-based branched rolling circle amplification for chemiluminescence detection of DNA methylation. Chem Commun. 2013;49:6906-8. 
161. Dadmehr M, Hosseini M, Hosseinkhani S, Ganjali MR, Khoobi M, Behzadi $\mathrm{H}$, et al. DNA methylation detection by a novel fluorimetric nanobiosensor for early cancer diagnosis. Biosens Bioelectron. 2014;60:35-44.

162. Zhang R, Nakahira K, Guo X, Choi AMK, Gu Z. Very short mitochondrial DNA fragments and heteroplasmy in human plasma. Sci Rep. 2016;6:1-10.

163. Fadeev E, De Pascale F, Vezzi A, Hübner S, Aharonovich D, Sher D. Why close a bacterial genome? The plasmid of Alteromonas macleodii HOT1A3 is a vector for inter-specific transfer of a flexible genomic Island. Front Microbiol. 2016;7:1-13.

164. Hall AB, Yassour M, Sauk J, Garner A, Jiang X, Arthur T, et al. A novel Ruminococcus gnavus clade enriched in inflammatory bowel disease patients. Genome Med. 2017;9:1-12.

165. Schoenfelder S, Javierre BM, Furlan-Magaril M, Wingett SW, Fraser P. Promoter capture $\mathrm{Hi}-\mathrm{C}$ : high-resolution, genome-wide profiling of promoter interactions. J Vis Exp. 2018;136:57320.

166. Baker MW, Atkins AE, Cordovado SK, Hendrix M, Earley MC, Farrell PM. Improving newborn screening for cystic fibrosis using next-generation sequencing technology: a technical feasibility study. Genet Med. 2016;18:231-8.

167. Hertz CL, Christiansen SL, Larsen MK, Dahl M, Ferrero-Miliani L, Weeke $\mathrm{PE}$, et al. Genetic investigations of sudden unexpected deaths in infancy using next-generation sequencing of 100 genes associated with cardiac diseases. Eur J Hum Genet. 2016;24:817-22.

168. Franasiak JM, Werner MD, Juneau CR, Tao X, Landis J, Zhan Y, et al. Endometrial microbiome at the time of embryo transfer: next-generation sequencing of the $16 \mathrm{~S}$ ribosomal subunit. J Assist Reprod Genet. 2016;33:129-36.

169. Kostareva A, Kiselev A, Gudkova A, Frishman G, Ruepp A, Frishman D, et al. Genetic spectrum of idiopathic restrictive cardiomyopathy uncovered by next-generation sequencing. PLoS ONE. 2016;11:1-16.

170. Kou R, Lam H, Duan H, Ye L, Jongkam N, Chen W, et al. Benefits and challenges with applying unique molecular identifiers in next generation sequencing to detect low frequency mutations. PLOS ONE. 2016:11:1-15.

171. Fisher KE, Zhang L, Wang J, Smith GH, Newman S, Schneider TM, et al. Clinical validation and implementation of a targeted nextgeneration sequencing assay to detect somatic variants in non-small cell lung, melanoma, and gastrointestinal malignancies. J Mol Diagn. 2016;18:299-315.

172. Weimer ET, Montgomery M, Petraroia R, Crawford J, Schmitz JL. Performance characteristics and validation of next-generation sequencing for human leucocyte antigen typing. J Mol Diagn. 2016;18:668-75.

173. He J, Song W, Yang J, Lu S, Yuan Y, Guo J, et al. Next-generation sequencing improves thalassemia carrier screening among premarital adults in a high prevalence population: the Dai nationality, China. Genet Med. 2017;19:1022-31.

174. Operario DJ, Koeppel AF, Turner SD, Bao Y, Pholwat S, Banu S, et al. Prevalence and extent of heteroresistance by next generation sequencing of multidrug-resistant tuberculosis. PLOS ONE. 2017;12:1-14.

175. Dirani G, Paesini E, Mascetra E, Farabegoli P, Dalmo B, Bartolini B, et al. A novel next generation sequencing assay as an alternative to currently available methods for hepatitis C virus genotyping. J Virol Methods. 2018;251:88-91.

176. Arias A, López P, Sánchez R, Yamamura Y, Rivera-Amill V. Sanger and next generation sequencing approaches to evaluate HIV-1 virus in blood compartments. Int J Environ Res Public Health. 2018;15:1-10.

177. Xu D, Huang X, Guo J, Ma X. Automatic smartphone-based microfluidic biosensor system at the point of care. Biosens Bioelectron. 2018;110:78-88.

178. Chen Y, Lin J, Jiang Q, Chen Q, Zhang S, Li L. A magnetic nanoparticle based nucleic acid isolation and purification instrument for DNA extraction of Escherichia coli O157: H7. J Nanosci Nanotechnol. 2016;16:2296-300.

179. Wang C, Zhu H, Chen Z, Deng Y, Su E, Xiao P. Control methods of mechanical arms motion for automatic nucleic acid detection system based on magnetic nanoparticles. J Nanosci Nanotechnol. 2016;16:12455-9.

180. Zhu C, Hu A, Cui J, Yang K, Zhu X, Liu Y, et al. A lab-on-a-chip device integrated DNA extraction and solid phase PCR array for the genotyping of high-risk HPV in clinical samples. Micromachines. 2019;10:537.
181. Huang RSP, Johnson CL, Pritchard L, Hepler R, Ton TT, Dunn JJ. Performance of the Verigene ${ }^{\circledR}$ enteric pathogens test, Biofire FilmArrayTM gastrointestinal panel and Luminex $\times T_{A} G^{\circledR}$ gastrointestinal pathogen panel for detection of common enteric pathogens. Diagn Microbiol Infect Dis. 2016;86:336-9.

182. Buchan BW, Reymann GC, Granato PA, Alkins BR, Jim P, Young S. Preliminary evaluation of the Research-Use-Only (RUO) iCubate iC-GPC assay for identification of select gram-positive bacteria and their resistance determinants in blood culture broths. J Clin Microbiol. 2015;53:3931-4.

183. Yasmin R, Zhu H, Chen Z, Montagna RA. A modifiable microarray-based universal sensor: providing sample-to-results automation. Heliyon. 2016. https://doi.org/10.1016/j.heliyon.2016.e00179.

184. Liu M, Hu P, Zhang G, Zeng Y, Yang H, Fan J, et al. Copy number variation analysis by ligation-dependent PCR based on magnetic nanoparticles and chemiluminescence. Theranostics. 2015;5:71-85.

185. Ngo HT, Gandra N, Fales AM, Taylor SM, Vo-Dinh T. DNA detection and single nucleotide mutation identification using SERS for molecular diagnostics and global health. Adv Biomed Clin Diagn Surg Guid Syst XV. 2017. https://doi.org/10.1117/12.2268779.

186. Xu X, Chen J, Li B, Tang L, Jiang J. Single particle ICP-MS-based absolute and relative quantification of: E. coli O157 16S rRNA using sandwich hybridization capture. Analyst. 2019;144:1725-30.

187. Frohnmeyer E, Frisch F, Falke S, Betzel C, Fischer M. Highly affine and selective aptamers against cholera toxin as capture elements in magnetic bead-based sandwich ELAA. J Biotechnol. 2018;269:35-42.

188. Li X, Peng G, Cui F, Qiu Q, Chen X, Huang H. Double determination of long noncoding RNAs from lung cancer via multi-amplified electrochemical genosensor at sub-femtomole level. Biosens Bioelectron. 2018;113:116-23.

189. Amini A, Kamali M, Amini B, Najafi A, Narmani A, Hasani L, et al. Bio-barcode technology for detection of Staphylococcus aureus protein A based on gold and iron nanoparticles. Int J Biol Macromol. 2019;124:1256-63.

190. He L, Ding L, Yu S, Yu F, Tian Y, Xie X, et al. Self-assembled poly-HRP dual signal amplification strategy for high-sensitive detection of circulating miR-142-3p in human serum. Sensor Actuat B Chem. 2019;279:440-6.

191. Ren Z, Zhu X, Lv H, Liu H, He H, Zhang X, et al. A fluorescent method based on magnetic nanoparticles for detection of CGG trinucleotide repeat genes. New J Chem. 2019;43:1322-7.

192. Tian L, Qi J, Oderinde O, Yao C, Song W, Wang Y. Planar intercalated copper (II) complex molecule as small molecule enzyme mimic combined with $\mathrm{Fe}_{3} \mathrm{O}_{4}$ nanozyme for bienzyme synergistic catalysis applied to the microRNA biosensor. Biosens Bioelectron. 2018;110:110-7.

193. Wang L, Yao M, Fang $X$, Yao X. Novel competitive chemiluminescence DNA assay based on $\mathrm{Fe}_{3} \mathrm{O}_{4} @ \mathrm{SiO}_{2} @ \mathrm{Au}$-functionalized magnetic nanoparticles for sensitive detection of p53 Tumor suppressor gene. Appl Biochem Biotechnol. 2019;187:152-62.

194. Wen CY, Liu TT, Wu LL, Li YM, Sun JY, Zeng JB. Magnetic nanospheres for convenient and efficient capture and release of hepatitis B virus DNA. Talanta. 2019;197:605-11.

195. Özdemir V, Dove ES, Gürsoy UK, Şardaş S, Yıldııım A, Yılmaz ŞG, et al. Personalized medicine beyond genomics: alternative futures in big data - proteomics, environtome and the social proteome. J Neural Transm. 2017;124:25-32.

196. Weisenfeld NI, Kumar V, Shah P, Church DM, Jaffe DB. Direct determination of diploid genome sequences. Genome Res. 2017;27:757-67.

197. Howell KJ, Kraiczy J, Nayak KM, Gasparetto M, Ross A, Lee C, et al. DNA methylation and transcription patterns in intestinal epithelial cells from pediatric patients with inflammatory bowel diseases differentiate disease subtypes and associate with outcome. Gastroenterology. 2018;154:585-98.

198. Takeuchi M, Mizuki N, Meguro A, Ombrello MJ, Kirino Y, Satorius C, et al. Dense genotyping of immune-related loci implicates host responses to microbial exposure in Behçet's disease susceptibility. Nat Genet. 2017:49:438-43.

199. van Asten F, Simmons M, Singhal A, Keenan TD, Ratnapriya R, Agrón E, et al. A deep phenotype association study reveals specific phenotype associations with genetic variants in age-related macular degeneration: age-related eye disease study 2 (AREDS2) report no. 14. Ophthalmology. 2018;125:559-68. 
200. Uppu S, Krishna A, Gopalan RP. A Review on Methods for Detecting SNP Interactions in High-Dimensional Genomic Data. IEEE/ACM Trans Comput Biol Bioinforma. 2018;15:599-612.

201. Jin Z, Liu Y. DNA methylation in human diseases. Genes Dis. 2018;5:1-8.

202. Rolandelli A, Del Pino REH, Pellegrini JM, Tateosian NL, Amiano NO, De La Barrera S, et al. The IL-17A rs2275913 single nucleotide polymorphism is associated with protection to tuberculosis but related to higher disease severity in Argentina. Sci Rep. 2017;7:1-11.

203. Mahdavi M, Nassiri M, Kooshyar MM, Vakili-Azghandi M, Avan A, Sandry $R$, et al. Hereditary breast cancer; Genetic penetrance and current status with BRCA. J Cell Physiol. 2019;234:5741-50.

204. Motawi TMK, Zakhary NI, Darwish HA, Abdalla HM, Tadros SA. Significance of serum survivin and $-31 \mathrm{G} / \mathrm{C}$ Gene polymorphism in the early diagnosis of breast cancer in Egypt. Clin Breast Cancer. 2019;19:276-82.

205. Li SY, Wu HC, Mai HF, Zhen JX, Li GS, Chen SJ. Microarray-based analysis of whole-genome DNA methylation profiling in early detection of breast cancer. J Cell Biochem. 2019;120:658-70.

206. Guarrera S, Viberti C, Cugliari G, Allione A, Casalone E, Betti M, et al. Peripheral blood DNA methylation as potential biomarker of malignant pleural mesothelioma in asbestos-exposed subjects. J Thorac Oncol. 2019;14:527-39.

207. Baldin AV, Grishina AN, Korolev DO, Kuznetsova EB, Golovastova MO Kalpinskiy AS, et al. Autoantibody against arrestin-1 as a potential biomarker of renal cell carcinoma. Biochimie. 2019;157:26-37.

208. Wang H, Liao P, Zeng SX, Lu H. It takes a team: a gain-of-function story of p 53-R249S. J Mol Cell Biol. 2019;11:277-83.

209. Puccini A, Loupakis F, Stintzing S, Cao S, Battaglin F, Togunaka R, et al. Impact of polymorphisms within genes involved in regulating DNA methylation in patients with metastatic colorectal cancer enrolled in three independent, randomised, open-label clinical trials: a meta-analysis from TRIBE, MAVERICC and FIRE-3. Eur J Cancer. 2019;111:138-47.

210. Geeitha S, Thangamani M. Qualitative analysis for improving prediction accuracy in Parkinson's disease detection using hybrid technique. J Comput Theor Nanosci. 2019;16:393-9.

211. Soozanipour A, Taheri-Kafrani A, Barkhori M, Nasrollahzadeh M. Preparation of a stable and robust nanobiocatalyst by efficiently immobilizing of pectinase onto cyanuric chloride-functionalized chitosan grafted magnetic nanoparticles. J Colloid Interface Sci. 2019;536:261-70.

212. Mohammadi M, Rezaei Mokarram R, Ghorbani M, Hamishehkar H. Inulinase immobilized gold-magnetic nanoparticles as a magnetically recyclable biocatalyst for facial and efficient inulin biotransformation to high fructose syrup. Int J Biol Macromol. 2019;123:846-55.

213. Hu P, Chang T, Chen WJ, Deng J, Li SL, Zuo YG, et al. Temperature effects on magnetic properties of $\mathrm{Fe} 3 \mathrm{O} 4$ nanoparticles synthesized by the solgel explosion-assisted method. J Alloys Compd. 2019;773:605-11.

214. Xie H, Dong J, Duan J, Hou J, Ai S, Li X. Magnetic nanoparticles-based immunoassay for aflatoxin B1 using porous g-C3N4 nanosheets as fluorescence probes. Sensor Actuat B Chem. 2019;278:147-52.

215. Suo H, Gao Z, Xu L, Xu C, Yu D, Xiang X, et al. Synthesis of functional ionic liquid modified magnetic chitosan nanoparticles for porcine pancreatic lipase immobilization. Mater Sci Eng C. 2019;96:356-64.

216. Qing T, Zhang K, Qing Z, Wang X, Long C, Zhang P, et al. Recent progress in copper nanocluster-based fluorescent probing: a review. Microchim Acta. 2019;186:670.

217. Hu M, Huang P, Suo L, Wu F. Polydopamine-based molecularly imprinting polymers on magnetic nanoparticles for recognition and enrichment of ochratoxins prior to their determination by HPLC. Microchim Acta. 2018;185:3-8.

218. Sulaiman GM, Tawfeeq AT, Naji AS. Biosynthesis, characterization of magnetic iron oxide nanoparticles and evaluations of the cytotoxicity and DNA damage of human breast carcinoma cell lines. Artif Cells Nanomed Biotechnol. 2018:46:1215-29.

219. Salk JJ, Schmitt MW, Loeb LA. Enhancing the accuracy of next-generation sequencing for detecting rare and subclonal mutations. Nat Rev Genet. 2018;19:269-85.

220. Attri S, Nagpal R, Goel G. High throughput sequence profiling of gut microbiome in Northern Indian infants during the first four months and its global comparison. Meta Gene. 2018;17:184-91.

221. Sequencing HSRNA, Herman JS, Pospisilik JA, Gru D. Chapter 15. 2018;1766:257-83.
222. Jin BF, Ji ZY, Su ZY, Mei LB, Huang XJ, Lin SB, et al. Identification of a novel mutation in FGFR1 gene in patients with Kallmann syndrome by high throughput sequencing. Syst Biol Reprod Med. 2018;64:202-6.

223. Ameur A, Kloosterman WP, Hestand MS. Single-molecule sequencing: towards clinical applications. Trends Biotechnol. 2019;37:72-85.

224. Denny SK, Greenleaf WJ. Linking RNA sequence, structure, and function on massively parallel high-throughput sequencers. CSH Perspect Biol. 2019;11:11.

225. Kvikstad EM, Piazza P, Taylor JC, Lunter G. A high throughput screen for active human transposable elements. BMC Genomics. 2018;19:1-14.

226. Coll F, Phelan J, Hill-Cawthorne GA, Nair MB, Mallard K, Ali S, et al. Genome-wide analysis of multi- and extensively drug-resistant Mycobacterium tuberculosis. Nat Genet. 2018:50:307-16.

227. Ziller MJ, Hansen KD, Meissner A, Aryee MJ. Coverage recommendations for methylation analysis by whole-genome bisulfite sequencing. Nat Methods. 2015;12:230-2.

228. Shieh JTC. Genomic sequencing expansion and incomplete penetrance. Pediatrics. 2019;143:22-6.

229. Gupta A. Nucleic acids. Compr Biochem Dent. 2019. https://doi. org/10.1007/978-981-13-1035-5_8.

230. Tamma PD, Fan Y, Bergman Y, Pertea G, Kazmi AQ, Lewis S, et al. Applying rapid whole-genome sequencing to predict phenotypic antimicrobial susceptibility testing results among carbapenem-resistant klebsiella pneumoniae clinical isolates. Antimicrob Agents Chemother. 2019;63:1-12.

231. Taylor CR. Introduction to predictive biomarkers: definitions and characteristics. In: Predict Biomarkers Oncol. 2019. p. 3-18.

232. Zhang Y, Ptacin JL, Fischer EC, Aerni HR, Caffaro CE, San Jose K, et al. A semi-synthetic organism that stores and retrieves increased genetic information. Nature. 2017;551:644-7.

233. Qasim A, Turcotte M, de Souza RJ, Samaan MC, Champredon D, Dushoff $J$, et al. On the origin of obesity: identifying the biological, environmental and cultural drivers of genetic risk among human populations. Obes Rev. 2018;19:121-49.

234. Kako K, Kim JD, Fukamizu A. Emerging impacts of biological methylation on genetic information. J Biochem. 2019;165:9-18.

235. Yang W, Lu Z, Zhi Z, Liu L, Deng L, Jiang X, et al. High-throughput transcriptome-Seq and small RNA-Seq reveal novel functional genes and microRNAs for early embryonic arrest in humans. Gene. 2019;697:19-25.

236. Hersh CP, Adcock IM, Celedón JC, Cho MH, Christiani DC, Himes BE, et al. High-throughput sequencing in respiratory, critical care, and sleep medicine research an official American thoracic society workshop report. Ann Am Thorac Soc. 2019;16:1-16.

237. Wei C, Zhong J, Hu T, Zhao X. Simultaneous detection of Escherichia coli O157:H7, Staphylococcus aureus and Salmonella by multiplex PCR in milk. 3 Biotech. 2018:8:1-7.

238. McCartney DL, Walker RM, Morris SW, Anderson SM, Duff BJ, Marioni RE, et al. Altered DNA methylation associated with a translocation linked to major mental illness. npj Schizophr. 2018;4:5.

239. Henritzi D, Hoffmann B, Wacheck S, Pesch S, Herrler G, Beer M, et al. A newly developed tetraplex real-time RT-PCR for simultaneous screening of influenza virus types A, B, C and D. Influenza Other Respir Viruses. 2019;13:71-82.

240. Wang P, Huang Y, Peng X, Huang Y, Chen D, Li S, et al. Toxicity-based typing of clostridioides difficile by loop-mediated isothermal amplification (LAMP) in critically ill patients. Nanosci Nanotechnol Lett. 2019;11:569-75.

241. Zhao J, Ragupathy V, Liu J, Wang X, Vemula SV, El Mubarak HS, et al. Nanomicroarray and multiplex next-generation sequencing for simultaneous identification and characterization of influenza viruses. Emerg Infect Dis. 2015;21:400-8.

242. Zhang H, Xu Y, Fohlerova Z, Chang H, Iliescu C, Neuzil P. LAMP-on-achip: revising microfluidic platforms for loop-mediated DNA amplification. TrAC Trends Anal Chem. 2019;113:44-53.

243. Green BJ, Saberi Safaei T, Mepham A, Labib M, Mohamadi RM, Kelley SO. Beyond the capture of circulating tumor cells: next-generation devices and materials. Angew Chemie Int Ed. 2016;55:1252-65.

244. Zhou L, Gan N, Hu F, Li T, Cao Y, Wu D. Microchip electrophoresis array-based aptasensor for multiplex antibiotic detection using 
functionalized magnetic beads and polymerase chain reaction amplification. Sensor Actuat B Chem. 2018;263:568-74.

245. Oberacker P, Stepper P, Bond DM, Höhn S, Focken J, Meyer V, et al. Bio-On-Magnetic-Beads (BOMB): open platform for high-throughput nucleic acid extraction and manipulation. PLoS Biol. 2019;17:1-16.

246. Huang X, Aguilar ZP, Xu H, Lai W, Xiong Y. Membrane-based lateral flow immunochromatographic strip with nanoparticles as reporters for detection: a review. Biosens Bioelectron. 2015;75:166-80.

247. Chen J, Andler SM, Goddard JM, Nugen SR, Rotello VM. Integrating recognition elements with nanomaterials for bacteria sensing. Chem Soc Rev. 2017:46:1272-83.

248. Miao P, Tang Y, Wang L. DNA modified $\mathrm{Fe}_{3} \mathrm{O}_{4} @ A$ Au magnetic nanoparticles as selective probes for simultaneous detection of heavy metal ions. ACS Appl Mater Interfaces. 2017:9:3940-7.

249. Gobbo OL, Sjaastad K, Radomski MW, Volkov Y, Prina-Mello A. Magnetic nanoparticles in cancer theranostics. Theranostics. 2015;5:1249-63.

250. Laing S, Gracie K, Faulds K. Multiplex in vitro detection using SERS. Chem Soc Rev. 2016;45:1901-18.

251. Carloni E, Rotundo L, Brandi G, Amagliani G. Rapid and simultaneous detection of Salmonella spp., Escherichia coli O157, and Listeria monocytogenes by magnetic capture hybridization and multiplex real-time PCR. Folia Microbiol. 2018;63:735-42.

252. Povedano E, Valverde A, Montiel VRV, Pedrero M, Yáñez-Sedeño $P$, Barderas $R$, et al. Rapid electrochemical assessment of tumor suppressor gene methylations in raw human serum and tumor cells and tissues using immunomagnetic beads and selective DNA hybridization. Angew Chemie Int Ed. 2018;57:8194-8.

253. Jimenez Jimenez AM, Moulick A, Richtera L, Krejcova L, Kalina L, Datta R, et al. Dual-color quantum dots-based simultaneous detection of HPVHIV co-infection. Sensor Actuat B Chem. 2018;258:295-303.

254. Liu ZY, Liu YC, Shen SH, Wu DC. Progress of recyclable magnetic particles for biomedical applications. J Mater Chem B. 2018;6:366-80.

255. Wu LH, Mendoza-Garcia A, Li Q, Sun SH. Organic phase syntheses of magnetic nanoparticles and their applications. Chem Rev. 2016;116:10473-512.

256. Defaei M, Taheri-Kafrani A, Miroliaei M, Yaghmaei P. Improvement of stability and reusability of a-amylase immobilized on naringin functionalized magnetic nanoparticles: a robust nanobiocatalyst. Int J Biol Macromol. 2018;113:354-60.

257. Bohara RA, Thorat ND, Pawar SH. Role of functionalization: strategies to explore potential nano-bio applications of magnetic nanoparticles. RSC Adv. 2016;6:43989-4012.

\section{Publisher's Note}

Springer Nature remains neutral with regard to jurisdictional claims in published maps and institutional affiliations.
Ready to submit your research? Choose BMC and benefit from:

- fast, convenient online submission

- thorough peer review by experienced researchers in your field

- rapid publication on acceptance

- support for research data, including large and complex data types

- gold Open Access which fosters wider collaboration and increased citations

- maximum visibility for your research: over $100 \mathrm{M}$ website views per year

At BMC, research is always in progress.

Learn more biomedcentral.com/submissions 